AN ANALYSIS OF THE TUITION PRICE ELASTICITY OF

INTERNATIONAL UNDERGRADUATES AT FOUR-YEAR INSTITUTIONS

IN THE UNITED STATES

A Dissertation
presented to
the Faculty of the Graduate School
at the University of Missouri
In Partial Fulfillment
of the Requirements for the Degree
Doctor of Philosophy
JIE ZHANG
Dr. Bradley Curs, Dissertation Advisor
MAY 2014


The undersigned, appointed by the dean of the Graduate School, have examined the dissertation entitled

AN ANALYSIS OF THE TUITION PRICE ELASTICITY OF

INTERNATIONAL UNDERGRADUATES AT FOUR-YEAR INSTITUTIONS

IN THE UNITED STATES

presented by Jie Zhang,

a candidate for the degree of doctor of philosophy,

and hereby certify that, in their opinion, it is worthy of acceptance.

Professor Bradley Curs

Professor Casandra Harper

Professor James Sebastian

Professor Joan Hermsen 


\section{DEDICATION}

I dedicate this dissertation to my dear mom, Chunzhen Guo, my beloved husband, Zhiqiang Zhang, and my three precious daughters, Dorothy, Alena, and Baylee! Your wholehearted support has made a world of difference in my life! I love you all forever! 


\section{ACKNOWLEDGEMENTS}

There are many people to whom I owe an enormous debt of gratitude and I want to say a big "THANK YOU" to all of you!

Dr. Bradley Curs, my advisor, has provided constant support and inspiration. I definitely could not have completed this dissertation without you. I truly appreciate your patience, care, and guidance throughout the six years of my doctoral study and this long and difficult dissertation process.

My most wonderful committee members, Dr. Casandra Harper, Dr. James Sebastian, and Dr. Joan Hermsen, thank you so much for your willingness to be my committee members and stay with me all the time through my comprehensive exam, research proposal, and ultimately the defense of this dissertation!

Finally, huge thanks go to my dear family and friends who have given me endless love and encouragement during this unique dissertation journey! I am really fortunate that I have all of you, near or far! 


\section{TABLE OF CONTENTS}

ACKNOWLEDGEMENTS....

ii

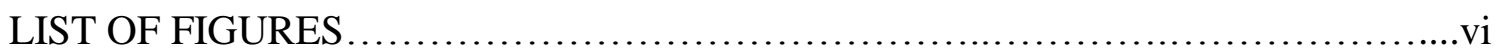

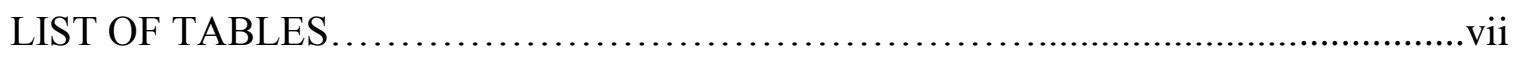

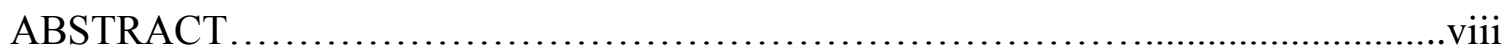

\section{Chapter}

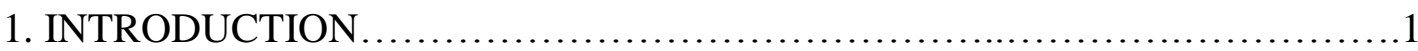

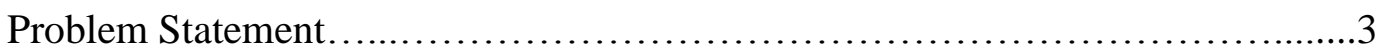

Research Purpose and Research Questions...........................................5

Theoretical Framework...................................................6

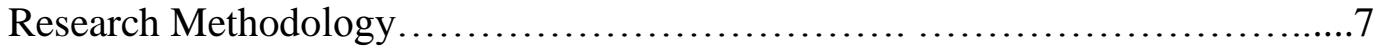

Significance of the Research.......................................... 8

Definition of Key Terms.............................................. 10

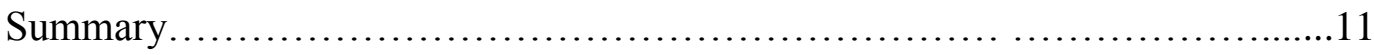

2. LITERATURE REVIEW \& THEORETICALFRAMEWORK..................13

Literature Review: U.S. Higher Education and International Students.............14

Benefits of Hosting International Students.................................14

The U.S. in Global Higher Education Market.............................18

Driving Factors Affecting International Students Coming to the U.S....... .22

Push and Pull: Encouraging International Students to Come in.........24

Push and Pull: Discouraging International Students from Coming in.....26

Summary of Background Literature.............................27

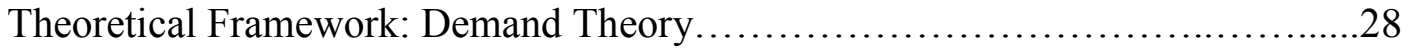


Price of Higher Education Institutions............................ 31

Student Financial Ability.............................................34

Student Preferences: Institutional Type and Quality..................38

Summary of Theoretical Framework..............................43

3. RESEARCH METHODOLOGY .......................................45

Rationale...........................................................46

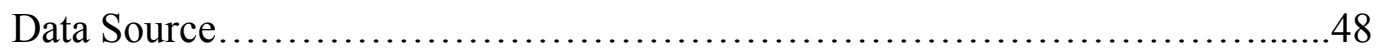

Sample..........................................................50

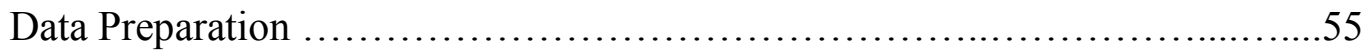

Variable Definitions.................................................56

Dependent Variable ...............................................56

Independent Variables.........................................57

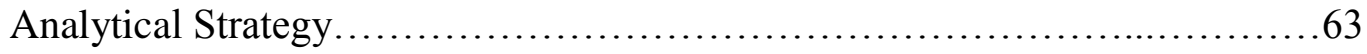

Summary........................................................65

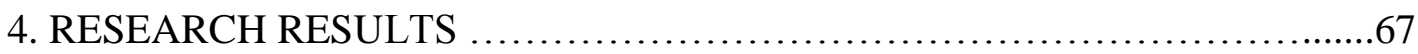

Full Sample Analysis (1991-2010)......................................68

Descriptive Statistics.......................................68

Fixed Effects Regression Analysis.................................72

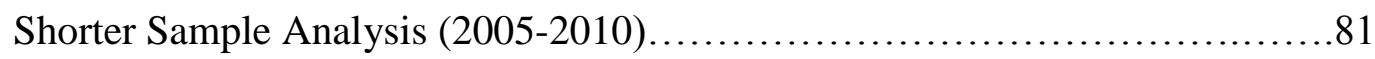

Descriptive Statistics...................................... 81

Fixed Effects Regression Analysis................................85

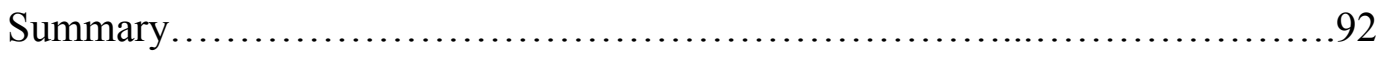

5. CONCLUSIONS AND IMPLICATIONS................................. 94 
Overview of the Study .94

Discussion of the Research Findings.................................... 96

Research Question One.........................................96

Research Question Two..........................................98

Comparison of Results across Sample Periods...................................100

Implications for Theory and Institutional Policy..........................103

Implications for Demand Theory...............................103

Implications for Institutional Policy.............................105

Limitations of This Study and Implications for Future Research..............107

Conclusion........................................................... 109

REFERENCES ............................................................. 111

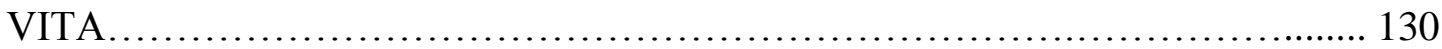




\section{LIST OF FIGURES}

$\begin{array}{lll}\text { Figure } & \text { Page }\end{array}$

1. International Undergraduate Student Enrollment Trend......................53

2. Change of Out-of-State Tuition and fees between 4-year and 2-year

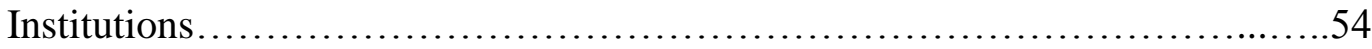

3. International Undergraduate Enrollment in 4-year and 2-year Institutions.........54 


\section{LIST OF TABLES}

Table

Page

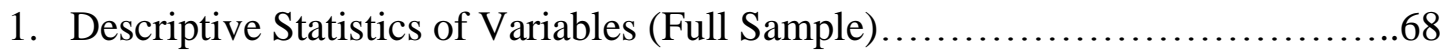

2. Descriptive Statistics of Variables by Carnegie Institution

Type (Full Sample)........................................... 70

3. Descriptive Statistics of Variables by Control (Full Sample) $\ldots \ldots \ldots \ldots \ldots \ldots \ldots \ldots 71$

4. Enrollment Effects of Tuition Increases: All Institutions (Full Sample)..........73

5. Enrollment Effects of Tuition Increases: By Carnegie

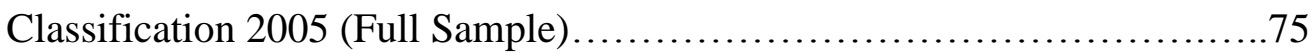

6. Price Elasticity by Carnegie 2005 Institution Type (Full Sample)..............78

7. Enrollment Effects of Tuition Increases: By Control (Full Sample).............79

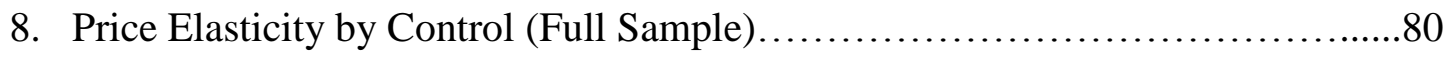

9. Descriptive Statistics of Variables (Shorter Sample)......................... 81

10. Means Comparison of Variables by Carnegie Institution

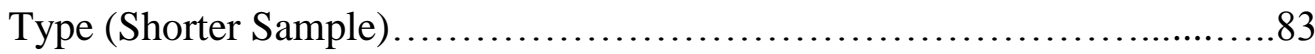

11. Descriptive Statistics of Variables by Control (Shorter Sample)................84

12. Enrollment Effects of Tuition Increases (Shorter Sample)..................... 86

13. Enrollment Effects of Tuition Increases: By Carnegie

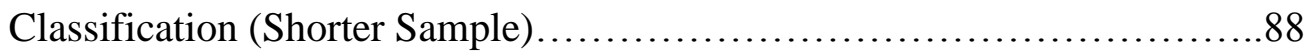

14. Price Elasticity by Carnegie 2005 Institution Type (Shorter Sample)............90

15. Enrollment Effects of Tuition Increases: By Control (Shorter Sample)..........91

16. Price Elasticity by Control (Shorter Sample) ........................... 92 


\title{
AN ANALYSIS OF THE TUITION PRICE ELASTICITY OF \\ INTERNATIONAL UNDERGRADUATES AT FOUR-YEAR INSTITUTIONS \\ IN THE UNITED STATES
}

Jie Zhang

Dr. Bradley Curs, Dissertation Supervisor

\begin{abstract}
The purpose of this study is to examine how out-of-state tuition and fees affects international undergraduate enrollment at U.S. four-year institutions. This study adopts the student demand theory as the theoretical framework to guide the quantitative design of the research. The data source was the Delta Cost Project version of IPEDS. The dependent variable of this study was the total number of international undergraduate enrollment at a four-year institution. The key independent variable was the out-of-state tuition and fees charged by an institution. Additionally, three vectors of variables for measuring the quality of institutional inputs, process, and outputs respectively were added as controls. Analytically, fixed effects regression was conducted to both a full sample data range from 1991 to 2010 and a shorter sample focused on the specific period of 2005-2010. The results of this study suggest international undergraduate students are generally inelastic to the changes of tuition and fees during the last two decades (19912010), but tend to become less inelastic in recent years (2005-2010). However, this general inelastic relationship between international undergraduate enrollment and tuition and fees can vary significantly across different institution types. The findings of this study have important implications to student demand theory, institutional policy-making and future research.
\end{abstract}




\section{CHAPTER ONE: INTRODUCTION}

International students have become an increasingly important student group on campuses of U.S. higher education institutions. The number of international students enrolled in U.S. colleges and universities reached a new record high of 819,644 in the academic year of 2012-2013 (Open Doors, 2013). International students have contributed more than $\$ 24$ billion to the U.S. economy in 2012-2013 through their expenditures on tuition and living expenses (Department of Commerce, 2013). Universities are relying on international students to fill critical skill gaps in science, technology, engineering, and math fields (STEM) with over $40 \%$ of international students enrolled in those fields leading to international students earning about one-third or more of all U.S. graduate degrees in STEM fields (Open Doors, 2009). Apart from the economic and academic aspects, U.S. higher education institutions also support international student recruitment for the reasons of enhancing cultural diplomacy, innovation and productivity by gaining access to talent, and promoting campus internationalization (Altbach, 2004; Altbach \& Knight, 2007; Marginson, 2004). As the importance of knowledge economy increases, U.S. institutions need more efforts to attract the best and brightest minds to maintain a highly skilled work force and stay globally competitive (Scott, 2007).

One important change in recent composition of international students is the dramatic increase of both the total number and the increasing rate of international undergraduate students. Data form Open Doors (2013) reveals that in the academic year of 2011-2012, for the first time in the history, international undergraduate students $(309,342)$ outnumbered international graduate students $(300,430)$ in U.S. higher education. In 2013, the total number of international undergraduate students reached 
339,933 or $42 \%$ of all international students in the U.S. while that number was 184,527 in 1990 and 254,429 in 2000 respectively. Also, the enrollment growth at the undergraduate level is set to outstrip growth at the graduate levels (Choudaha \& Chang, 2012). For the year of 2013, the total number of international undergraduate students increased 30,651 which mean a $10 \%$ increase over 2012. In contrast, the total number of international graduate students increased 10,774 which mean a 3.6\% increase from 2012. This increasing rate of international undergraduate students was roughly $6 \%$ for both 2011 and 2012, in sharp contrast to the increasing rate of $1 \%$ in 2011 and 2012 for international graduate students (Open Doors, 2013).

A remarkable feature of today's international undergraduate students is their proclivity to be a full-fee paying student which helps explain why international undergraduate students receive more attention than ever in recent higher education research and practice. Data from National Postsecondary Student Aid Study (NPSAS:08) show that although many graduate international students hold assistantships and fellowships, the majority of undergraduate international students (82\%) rely primarily upon personal and family funds to pay for their studies. Data from Open Doors (2013) reconfirms this trend. Another fact is, although international students are seen enrolling into various types of U.S. higher education institutions, more than $80 \%$ of them are degree/certificate seekers in four-year institutions (Open Doors, 2013). From an institutional revenue perspective, international students pursuing undergraduate degrees typically provides a longer stream of revenue (four years) versus Master's or Associate's programs (two years) and makes some institutions view this trend as a solution to their current fiscal challenges. 


\section{Problem Statement}

Studies show U.S. higher education is remaining attractive to international students, but its once-dominant position is eroding (Douglass \& Edelstein, 2009) and the U.S. may continue to lose its market share in attracting international students over time. Available data indicate many global competitors (e.g. U.K., Australia, New Zealand, Canada and others) are increasing their capability to attract international talent. Even though the U.S. still dominates the market in terms of student numbers, and remains a major global provider of doctoral and other research-related degrees, with $24 \%$ of all graduate students coming from foreign countries, the ratio of international graduate student number to total graduate student number is $30 \%$ in Australia, $43 \%$ in UK and $35 \%$ in France. This gives the U.S. further pressure to increase its attractiveness in the global higher education market.

Also, U.S. higher education has recently witnessed a decline in several of its wellestablished markets, including Indonesia, Japan, Taiwan and Thailand (OECD, 2010). Moreover, among other leading destination countries, the U.S. has experienced comparatively weak growth in international student enrollment overall. There were strong increases in the number of students from a few countries, but more than half of 25 sending countries showed decreases, resulting in a slower rate of overall growth than had been seen in recent years. Consequently, the U.S. share of international students worldwide dropped between 2000 and 2008 from 26\% to 20\% (Open Doors, 2009). In the long term, this will make the U.S. which is highly dependent on global immigration of talented students and professionals most vulnerable to downward access to global talent, with a potentially significant impact on future economic growth. 
To assure the great economic, academic, and cultural benefits that international students bring to the U.S. (Chellaraj, Maskus, \& Mattoo, 2008; Cushner \& Mahon, 2002), studies from Government Accountability Office (Scott, 2007) recommend the U.S. achieve a national goal of doubling the number of international students over the next decade (e.g. 1.5 million international students by 2020) to match numbers in a group of competitor nations. In particular, less than $2 \%$ of overall enrollment in the U.S. is from international undergraduate students while it is estimated that a more globally competitive percentage would be about 10\% (Douglass \& Edelstein, 2009). At the same time, current U.S. higher education is faced with the shrinking pool of domestic traditional student enrollments, budget deficits, and retrenchment in an age of rising student consumerism. Many colleges and universities began to pay increased attention to recruitment of qualified students from pools of prospective students that are not shrinking, such as non-traditional, women, part-time students, minorities, and international students. Therefore, seeking for more qualified international students to meet their enrollment goals is an important strategy for many U.S. higher education institutions to cope with the changing domestic higher education market.

Unfortunately, there is still lack of knowledge about international undergraduate student college choice behavior to effectively inform institutional enrollment planning, student marketing, and recruitment. The fall 2012 Snapshot Survey released by Institute of International Education (IIE) confirmed the positive effects of active institutional recruitment efforts that drive the growth in enrollments on many U.S. campuses. More than two-thirds of all responding institutions (69\%) have taken special steps to ensure that the number of international students on their campuses does not decline. It indicates 
institutions which are seeking more effective ways to respond to both its domestic situation and global challenge need increase their efforts to improve market-oriented recruiting strategies.

\section{Research Purpose and Research Questions}

The purpose of this study is to examine whether international undergraduate student enrollment is related to the changes of institutional tuition and fees. Specifically, how does the change of out-of-state tuition and fees affect international undergraduate student enrollment at U.S. four-year institutions. This study was motivated by research results showing that the cost of obtaining a U.S. degree is among the highest in the world and rising (Scott, 2007). Strategic and proactive marketing plan is important for advocating the unique benefits for international students studying in the U.S. and enhancing the attractiveness of U.S. higher education (Douglass, 2006; Green, Marmolejo \& Egron-Polak, 2012; Naidoo, 2010). Also, the cost of attendance is proved to be a significant factor that most U.S. domestic students use to eliminate schools from their considerations. Typically, domestic students tend to preselect institutions based on cost, institutional categories or types, distance from home, selectivity, and others (Paulsen, 1990).However, there is no prior empirical evidence showing whether international students consider similar factors as domestic undergraduate students when they enroll to U.S. institutions.

The two specific research questions for this study are:

1) Is international undergraduate enrollment related to changes in institutional out-of-state tuition and fees? 
2) Is the relationship between international undergraduate enrollment and out-ofstate tuition and fees moderated by institutional type?

\section{Theoretical Framework}

The theoretical framework of this study is higher education student demand theory. Student demand studies are investigations into the economic factors that affect student enrollment based on demand theory in economics. Demand theory in economics holds that the quantity of a particular good or service demanded is affected by the price of the good or service, the income of the buyer, and the buyers' tastes or preferences (Leslie \& Brinkman, 1987). The goal of student demand research in U.S. higher education is therefore, to find out if the student enrollment level is affected by the cost of attendance, the financial ability of students and students' tastes or preferences concerning various institutional or individual characteristics. Generally speaking, it suggests that enrollment would decrease as tuition increases and inversely, enrollment would increase as tuition decreases. Although student demand studies have been studied for decades by using different statistical techniques, data sources, and institutional population, the majority of the research is focused on the U.S. domestic students' college choice decisions.

International undergraduate students have increasingly become an important subgroup of student body in U.S. campuses and share a lot of common traits of the whole student body. For example, the idea behind the successful application of demand theory in understanding domestic students may also come true to international undergraduate students. International undergraduate students are one set of students who are considered as consumers of academic programs in higher education discourse where students are thought of as an important client (or even partner) of the university (Clayson \& Haley, 
2005). This idea makes international undergraduate students similar as any other student group in the whole student body when they are identified and evaluated not by any other unique traits they may have but by their perceived purchasing power in the process of college choice.

Also, there is a vast literature dealing with the general student body and their college choice models (Chapman, 1981; Hossler \& Gallagher, 1987; Litten, Sullivan, \& Brodigan, 1983) from different perspectives. Their conceptual foundations emphasize the formation of college going aspirations as part of a general status attainment process or the form of investment like decision making behavior. These models suggest the decision process of all the students pursuing college education consists of a number of common stages or phases in which various individual and organizational factors interact to produce outcomes that influence the next stage or phase. Thus, as assumed by economists, international undergraduate students are the same rational consumers as any other student groups. It is reasonable to apply demand theory which has been tested in domestic student enrollment studies, to the investigation of international undergraduate student enrollment in U.S. higher education.

\section{Research Methodology}

This study will adopt a quantitative research design by using a nationally representative large-scale data set. The data source of this study is the Delta Cost Project version of Integrated Postsecondary Education Data System (IPEDS) managed by the U.S. Department of Education, National Center for Education Statistics (NCES). IPEDS is a comprehensive database that includes a system of interrelated surveys of institutions. The longitudinal nature of the data sets in the IPEDS system is especially valuable for 
tracking patterns and trends over time. Prior studies have used the IPEDS as data source and achieved various important research purposes in higher education. The sample of this study will include 615 four-year institutions which offer undergraduate degree/certificate and report their international undergraduate student enrollment during the period of 19912010. Both public and private (non-profit) sectors are represented in the sample.

This study will use fixed effects regression method which examines variation within an institution over time to identify the relationship between tuition changes and international undergraduate student enrollment. The institutional fixed characteristics are included in the model to control for institution-specific factors and enable this study to control for unobservable institutional characteristics that are constant over the sample period. The data will be analyzed by using SAS which is one of the most convenient and powerful computer software programs for statistical analysis in educational research field. The analysis results will reveal the impact of out-of-state tuition and fees charged by an U.S. institution on its international undergraduate student enrollment and whether this impact is moderated by institution types.

\section{Significance of the Research}

Based on current literature, little is known about international undergraduate student enrollment behavior in U.S. higher education. Despite the wealth of information on college demand studies about how institutional features affect domestic students'

choice of attendance, there is very limited research on international students' demand and what factors are impacting their enrollment in specific institutions in the U.S. (Lee, 2008). Available domestic student college choice studies can reveal some trends to help understand international student enrollment behavior. However, Hossler and Gallagher 
(1987) clearly stated "student college choice is a complex phenomenon. Efforts of policy makers at the federal, state, and institutional levels to influence the college choice process will have to be more carefully targeted if they hope to increase their effectiveness" (p.218). Especially, in recent decade, as a new and viable discipline, international enrollment management (IEM) suggests strategies proved to be effective in domestic student enrollment may not be directly transplanted to international student enrollment management without considering the unique characteristics of international students (Sinclair, 2010).

Methodologically, previous studies about international student enrollment were conducted both by qualitative and quantitative methods. Some qualitative studies try to understand the perception of a small group of international students to their hosting institutional environment but most of them are institutions specific and not generalizable. Other quantitative studies may also focus on a small number of international students enrolled in one or several specific institutions by doing campus-wide surveys. The generalizability could be largely limited to the sample size and the students' background like ethnicity, nationality, major specialization, school type and region in the sample. There is a strong need to use a quality large-scale national representative data set to quantitatively identify the relationships between international student enrollment and U. S. higher education institutions.

Research based on large scale national level data has its inherited merits. On the one hand, Christie and Fleischer (2010) suggest when randomized controlled trials are not feasible, large-scale nationally representative studies may provide the best source of data on which to base educational policy decisions. On the other hand, for policy makers 
and campus administrators who want to recruit internationals, much of the current knowledge on the factors influencing international student college choices has been anecdotal rather than empirically based (Naidoo, 2010). Professionals in the field of international education often find themselves relying on hearsay as opposed to concrete empirical evidence in formulating policy directions and recruitment strategies. Thus, research about international students by using large scale data sets can provide informative perspectives and produce more generalizable results. This study will contribute to the higher education literature by filling up this methodology gap.

The anticipated results of this study are of great practical importance to administrators and decision-makers in U.S. higher education institutions. Evidence-based demand studies about international undergraduate students can enrich the fundamental knowledge base for designing international student recruitment strategies in their institutions. This study will specifically examine if out-of-state tuition and fees is an important factor related to an institution's total international undergraduate student enrollment. It can also help institutions forecast their enrollment by making the assumptions necessary to estimate revenue and expenditure in budgeting processes and understand the college going decision making process of desired international undergraduate students.

\section{Definition of Key Terms}

International undergraduate students: This research adopts the definition offered by IPEDS data set which refers to a person who is not a citizen or national of the United States and who is in this country on a visa or temporary basis for undergraduate degree/certificate seeking purpose and does not have the right to remain indefinitely. In 
the analysis steps, international undergraduate students are specifically referred to firsttime freshmen undergraduate degree/ certificate seeking students who officially enrolled in an accredited U.S. higher education institutions.

Out-of-state tuition and fees: It refers to the tuition and fees charged by institutions to those students who do not meet the institution's or state's residency requirements. This is also the tuition and fees charged for international students by U.S. institutions. Specifically in this study, it refers to the one fixed amount of money charged to an out-of-state full-time undergraduate student by an institution that covers tuition and required fees. For a reasonable comparison of the tuition and fees across years, this study has adopted an appropriate index variable to translate current dollar values into inflationadjusted 2010 dollars.

Institution type: This study adopts the collapsed version of the Carnegie 2005 Classification as the framework to represent institutional differences in the U.S. higher education. Considering the focus of this study is four-year institutions only, three-fold classification is adopted: Research/Doctoral institutions, Master's institutions, and Bachelor's institutions. In addition, control is also used to break all four-year institutions available in the sample into Public institutions and Private institutions as well.

\section{Summary}

This introductory chapter serves as an overview of the dissertation research. It provides the general background for the research by identifying the importance of international students in U.S. higher education and commenting on the U.S. practice of attracting international students in the increasingly competitive global higher education market. There is a strong need for U.S. higher education institutions to know more about 
international students' college choice behavior to improve recruitment strategies and assure the benefits of hosting international students. It explicitly set the purpose of the research as to find out whether tuition and fees is an important factor related to international undergraduate student enrollment in U.S. higher education. Two major research questions are also proposed. This research will make contribution to current literature on international student research and fills up the gap of lacking quantitative research on international undergraduate students based on national level large-scale data sets. Demand theory is adopted as the theoretical framework to guide the research design and variable selections. Fixed effects regression model is used to analyze both a full sample of 20-year data and a shorter sample of 6-year data. In the end, this chapter offers the definition of key terms used in this research. 


\section{CHAPTER TWO: LITERATURE REVIEW \& THEORETICAL FRAMEWORK}

A considerable amount of research has been conducted on international students since the 1950s, and this literature has continued to expand over the decades with the growing international student population in the world. Much of the research in U.S. higher education related to international students has largely involved investigation of international students in general and the problems these students have in academic performance and adjustment to the destination institutions (Galloway \& Jenkins, 2005; Grey, 2002; Lee \& Tan, 1984; Selvadurai, 1992). However, rather than focusing on the problems international students have run into after they landed on U.S. campuses, a broader view of driving forces or factors influencing international students to choose U.S. higher education as their study destination can provide an alternative perspective to understand the international students in the U.S. and the evolving relationship between U.S. higher education and the international students they are hosting. Admittedly, a large part of international student research in U.S. higher education is based upon research on domestic students. Among others, the increasing price of attendance has been widely reported as a negative influence to domestic student enrollment in U.S. higher education in recent decades (Hearn \& Longanecker, 1985; Hemelt \& Marcotte, 2011; John, 1990; Leslie \& Brinkman, 1987; Nutting, 2013).

The purpose of this study is to examine whether this relationship between the price and enrollment will apply to international undergraduate students, that is, whether the out-of-state tuition and fees charged by institutions affect international undergraduate student enrollment at U.S. higher education. To achieve this purpose, background 
literature is reviewed to better reveal the relationship between U.S. higher education and its international student enrollment. This review will cover three streams of research including the benefits of recruiting and hosting international students; the U.S. in global higher education market; and the driving factors affecting international students coming to the U.S. Following this review of the literature student demand theory is proposed to be the theoretical framework for shaping the methodological design of this research. Three major concepts of the demand theory including price, financial ability, and buyer's preferences are discussed from the international student's standpoint to further justify the choice of variables this study aims to examine.

\section{Literature Review: U.S. Higher Education and International Students}

\section{Benefits of Hosting International Students}

Research focused on benefits to nations and institutions of hosting international students are important (Heaton \& Throsby, 1998; Rose-Redwood, 2010; Williams, 1981) because it provides the rationale for strategically improving their international enrollment management and compete for more international talents. Traditionally, the U.S. is wellknown for building its vibrant higher education system by concerted effort to enroll international students and retain a sizable number of them in its national economy after graduation (Douglass \& Edelstein, 2009). Hosting students and scholars from all around the world has been an effective way to achieve internationalization and globalization of the U.S. higher education institutions (Altbach, 2004; Marginson, 2004; Sanderson, 2004). There has also been discussion on the effects that international students may have on the education of domestic student populations (Goodwin \& Nacht, 1983; Kimmel \& 
Volet, 2012; Lambert, 1993). In general, research concludes educating international students brings invaluable and irreplaceable benefits to U.S. higher education.

A major branch of studies of the benefits of educating international students relates to the economic contribution international students have made to hosting countries. In the U.S. international students contributed more than $\$ 24$ billion in 2013 to the U.S. economy through their expenditures on tuition and living expenses (Department of Commerce, 2012). It is reported that $62 \%$ of all international students receive the majority of their funds from personal and family sources (Open Doors, 2010). When other sources of foreign funding are included, such as assistance from their home country government or universities, almost $70 \%$ of all international students' primary funding comes from sources outside of the U.S. Many researchers have concluded that while the U.S. subsidizes international graduate students through graduate assistantships, it actually gains more from them economically because most (82\%) undergraduate international students pay tuition and all students spend money on living expenses (Abelmann \& Kang, 2013; Guruz, 2011). This increasing number of international students has made U.S. institutions realize a direct connection between the tuition revenue and their international student enrollment over the recent decades.

In turn, this revenue benefits have provided a strong economic reason for higher education institutions to firmly move to seek more international undergraduate students. For many universities, recruiting full-fee paying international undergraduate students is an important source of revenue at a time when many of these institutions, especially the public ones, are being faced with reduced state financial support and are having to operate under an increasingly market-orient approach (Kwiek, 2001). For example, at the 
University of California Berkeley campus, the number of international freshmen enrolled in fall 2011 increased by $50 \%$ as compared to the previous year. This translates to 196 additional international students and expected additional revenue of $\$ 18$ million over four years. Straubhaar (2000) even argues that international students have become a major money-generating machine for U.S. higher education. This revenue benefit for institutions also helped trigger the emergence of national education service industry in the U.S. (Mazzarol, Soutar, \& Seng, 2003). Recently, the revenue from international education services has become the fifth largest service sector export in the U.S. economy, closely following Australia and New Zealand where international education has climbed to be the third and fourth largest export industry in these two countries (Vincent-Lancrin, 2004).

Other studies have recognized international students' academic importance on hosting campuses (Altbach \& Wang, 1989; Barger, 2004; Chellaraj, Maskus, \& Mattoo, 2008; Magaya, 2004). International students make invaluable academic contributions because they enrich institutions' academic dialog and bring different expertise, unique perspectives into the learning communities in the U.S. (NAFSA, 2003) and help improve a range of student learning outcomes (Chang, Astin, \& Kim, 2004; Gurin, Dey, \& Hurtado, 2002). Especially, in the STEM field, more than $40 \%$ of enrolled students are international students (Open Doors, 2009). On the specific contribution that international students have made to research and innovation, Chellaraj, Maskus, and Mattoo (2008) indicate that the presence of foreign graduate students has a significant and positive impact on both future patent applications and future patents awarded to university and non-university institutions. As a fact, in the U.S., almost $20 \%$ of the distinguished 
scientists and engineers who are members of the National Academy of Sciences, and more than a third of U.S. Noble laureates, are foreign-born (Committee on Science \& Public Policy, 1987; Higdon, 2003).

Additionally, many institutions believe having international students on their campuses is essential in fostering cross-cultural exchanges. International students contribute greatly in terms of making U.S. college campuses more ethnically and culturally diverse (Furnham \& Alibhai, 1985; Zhao, Kuh, \& Carini, 2005) and help provide international insights to U.S. students who may never have the opportunity to study abroad but whose careers will demand global competencies (Cushner \& Mahon, 2002). For example, Sharma and Mulka (1993) imply that cross-cultural experience through international students can deepen domestic students' understanding about their own culture and share it effectively with people from different backgrounds and cultures. Also, international students are often catalysts of multiform cultural exchange and cooperation across international borders since many students retain strong ties to their home countries and create transnational connections (Selvaratnam, 1985). These positive interactions may promote future goodwill between nations as many international students are or will become leaders in their home countries (NAFSA, 2003; Douglass, 2006).

To sum up, there are considerable benefits for U.S. higher education involved in recruiting and hosting international students. The presence of international students are the important economic contributions that international students made during their multiple years of studying and living in the hosting countries, remaining in the hosting countries as highly skilled workers after graduation; the academic quality advancement to the hosting institutions including filling up certain programs that are lack of enrollment of 
domestic students and bringing in innovative knowledge to hosting institutions; the enrichment of cultural diversity to the institutions and valuable addition to the domestic students' overall learning experiences, and stimulate mutual beneficial international cooperation.

\section{The U.S. in Global Higher Education Market}

Global higher education market has become an important topic in higher education research concerning both the large and increasing international student population around the globe and the critical significance of competing with others and winning a good market share. According to the UNESCO Institute of Statistics, there were 3.7 million internationally mobile students worldwide in 2011, up from 1.8 million in 1999 and 0.25 million in 1965 . Traditionally, more than $90 \%$ of international students have enrolled in institutions in countries belonging to the Organization for Economic Cooperation and Development (OECD) with the five primary destinations (the U.S., the U.K., Germany, France and Australia) recruiting over $70 \%$ of them. Significant year-onyear growth was recorded in both the late 1990s to early 2000 s and the late 2000 s to 2010s in most of the main English-language destinations owing to robust economic advancement in several major source countries at the same periods, such as China and India providing a large number of enrollments each year (Open Doors, 2012).

However, research further shows that although the number of students seeking education abroad is growing and is likely to continue doing so, the global higher education landscape has changed since the 2000s (Douglass, 2006). The competition among institutions and countries for international students is becoming fierce (Green, Marmolejo, \& Egron-Polak, 2012). Institutions will have to compete hard for talented 
and self-funded students because with world markets shuddering, even higher education remains one of the few bright spots in a gloomy global economic landscape the range of programs on offer could soon exceed demand (Labi, 2008). Some of the main destination countries or institutions will or may have seen challenges to their dominant positions for the international students market (Murray, et.al, 2011).

At the first look, it is impressive that the U.S. keeps both the largest number of international students and also the largest share (20\%) of global international students compared with other major hosting countries, including Australia (17\%), the U.K. (14\%), France (11\%), Germany (11\%), and Canada (5\%). However, the picture looks different when considering the U.S. has the largest higher education capacity among the main competitors in the international student market, with more than 4,000 accredited institutions, international students account for $3.6 \%$ of its total higher education enrollments compared with the percentage of international students in the U.K. (15\%), Australia (21\%) and Canada (8\%) (Douglass \& Edelstein, 2009). This low percentage of international students in the U.S. will prevent its higher education institutions and the society as a whole from maximizing the benefits of hosting international students (Scott, 2007).

The growth rate of international student enrollment in the U.S. is much lower than its competitors. According to the American Council on Education (ACE, 2007), between 2000 and 2006, international enrollments to the U.S. grew by nearly 17\%, but the growth was $29 \%$ in the U.K., $42 \%$ in Australia, $46 \%$ in Germany, $81 \%$ in France, and $108 \%$ in Japan over the same period. One of the most agreed reasons for explaining this low growth rate in the U.S. is, as a top destination country, the U.S. already had a large 
base of international students, so even an additional large number of international students may only account for a comparatively small growth rate. However, other discouraging factors, like the increasingly escalating cost of degree studies, the lengthy and rigid visa processes, and discrimination related racial problems are often pointed out for serious consideration when attracting international students (Douglass \& Edelstein, 2009; McCormack, Neelakantan \& Overland, 2007).

It is noteworthy that outside of the U.S. many countries have realized global educational competitiveness is fundamental to their national development and begun to actively seek out for opportunities to expand their own education system to the global market. Human capital, knowledge and creativity, rather than natural resources, are considered as the keys to economic development (Staniscia, 2012). As a consequence, more and more countries have increasingly sought to attract international students, as part of a strategy to expand their knowledge economies. A growing infrastructure continues to be developed as countries compete for the world's students by establishing branch campuses, developing technology-based distance learning opportunities, hiring recruiters and international student specialists, and building service organizations related to international students to increase the flow of international students to particular destinations (Altbach, 2004).

In addition, the governments of those major U.S. competitors have adopted innovative approaches to reach and attract potential students including marketing their higher education to the international community much as a business would promote a product (Douglass \& Edelstein, 2009). There are emerging aggressive higher education marketing plans and presence of international recruiters in Australia and also changing 
policies in Canada that extend visa stays for international students (Shachar, 2006). In order to gain access to funds as well as further the internationalization of their universities, some English-speaking countries have gone so far as to point out to international students the advantages of studying in their universities as opposed to the U.S. universities through comprehensive recruitment campaigns. Advantages included lower tuition costs (Australia \& Canada), lower costs of living (Australia \& Canada), shorter degree programs (U.K. \& New Zealand), and fewer restrictions on working after completing a course of study (U.K. \& Canada) (Hindrawan, 2003; Mooney \& Neelakantan, 2004; “Wandering Scholars", 2005).

In a sign of shifting global power, some special-purpose organizations are also created at cross-government level to develop strategic plans or offices focusing on attracting international students (Scott, 2007). For example, the "Europeanization" of global higher education is, in fact, being promoted by organizations such as European Commission, the German Academic Exchange Service (DAAD), the Netherlands Organization for International Cooperation in Higher Education Office by encouraging international forums and national and institutional cooperative agreements. Some nonEnglish speaking countries make every effort to offer courses in English, for example, the Netherlands has many English degree programs and France has 400 Master's programs in English. Also, the European Union funded more than 100 joint degree programs for attracting international students to European higher education by combining resources from several institutions in different European countries (Robertson, 2008). However, there are no similar efforts by the U.S. government agencies that, in contrast to much of the developed and developing world, continue to view higher education as a domestic 
policy arena (Douglass \& Edelstein, 2009).McCormack, Neelakantan and Overland (2007) conclude that compared to its major competitors, too little is being done by the U.S. government to attract international students.

To sum up, although the trend for students pursuing international education in the world is kept consistent in recent decades with the large and increasing number, the global higher education landscape is changing. This part of literature review has compared the U.S. higher education with its major competitors and identified the competitive measures other nations are taking to increase their share of the global student market. In terms of sheer numbers, the U.S. dominates the international student market as a result of its established international reputation. However, the wide provision available in other countries may challenge the position of U.S. higher education in the global higher education market in the foreseeable future. Also, there is a lack of national (federal) level efforts to promote U.S. higher education as a whole unity to international students compared with other competitor countries (Scott, 2007). Rather, ongoing efforts of attracting and hosting international students are seen and made more at institutional level. Thus, with improving institutional quality and targeted recruitment initiatives many emerging international student hosting institutions in the U.S. have the potential to grow new markets and transform incoming mobility patterns. This is also a good reminder for the U.S. institutions to exert greater efforts to keep its competitiveness of hosting international students.

\section{Driving Factors Affecting International Students Coming to the U.S.}

Understanding factors affecting international students' choice of their study destination is critical for U.S. higher education to effectively manage their international 
enrollment (Lee, 2008). Studies about international education before 1984 found few studies that have investigated the drivers behind international student mobility (Lulat \& Cordaro, 1984; Naidoo, 2007). Agarwal and Winkler's (1985) comprehensive study about the international students in the U.S. from 15 developing countries throughout the post-second World War era was a milestone contribution in this field and suggested that the principal flow drivers were per capita income in the home country, the price or cost of education, the education opportunities available in the home country and the expected benefits of studying abroad after returning to their home country. Later, McMahon (1992) examined the flow of international students from 18 developing countries during the 1960s and 1970s and found a negative correlation between economic prosperity in the sending countries and the volume of international students flow. These early endeavors agreed that international student's deliberation on their higher education study destination is shaped by national, social and economic factors which may vary in some important respects from the decision of those domestic students.

The most representative attempt to understand international student's choice of study destination after 1990s focused on push-pull factors combined to drive students to a certain study destination (Lawley, 1997; Mazzarol \& Soutar, 2002; Pimpa, 2005; Shah \& Laino, 2006). Earlier push-pull studies about international students focused on identifying factors from source country as push factors to initiate a student's decision to undertake international study while identifying factors from destination country as pull factors to make that country relatively attractive to international students. Later push-pull studies are not satisfied with the simple two-way explanation to international student's decision making (Gonzalez, Mesanza, \& Mariel, 2011). The newer push-pull model argues that 
there are basically two combinations of forces at play: push-pull encouraging factors and push-pull discouraging factors which attempted to explain that multiple factors from different directions may work in combinations to affect the international students' choice of study destination (Becker \& Kolster, 2012). This set of research believes international student's choice of study destination is the total force of both the encouraging and discouraging push-pull factors.

\section{Push and Pull: Encouraging International Students to Come in}

The encouraging factors from both the source country and destination country could drive students away from their homeland and push or pull them to pursue their higher education in the international destination. Mazzarol and Soutar (2002) examined the factors motivating international student choice of the host country, and argued that economic and social forces within the home country may serve to "push" students abroad. Larsen and Vincent-Lancrin (2002) reported that in most developing countries higher education institutions can only accommodate less than $5 \%$ of those who demand post-secondary education. Common access related problems include unavailability of courses of choice in home institutions as well as inability of students to meet highly competitive entry requirements that may be in place due to supply not being able to meet demand (Mazzarol \& Soutar, 2002; Mpinganjira, 2009). For example, in China, some 5 million high school students passed the university entrance exams in 2001 and yet Chinese institutions could accommodate only less than half of that number (Kaufman \& Goodman, 2002). Thus, for some undergraduate students, studying in another country may be the only way of accessing higher education due to access related problems in their own countries (Alam, 2009). 
Research focused on characteristics of those push-pull factors also found that the relative large size, strong strength of the hosting country economy and the overall high reputation of the higher education system were encouraging factors to international students (Kolster, 2010; McMahon, 1992). Studies related to internationalization and globalization of higher education emphasized the attractiveness and quality of the international educational opportunities (Douglass, 2006). Li and Bray (2007) agree that the factors related to quality and reputation were the most important followed by factors relate to the funding and costs of the education and the environmental factors of the institution. The general results from this stream of research suggest that the characteristics of hosting nations have important influence to international students' choice of study destination and hosting countries should be able to pull international students to them when they meet the need of students to access high quality education and/or broaden their personal experiences (Mpinganjira, 2009).

At the institution level, Sinclair (2010) emphasizes institutions must have a great deal of knowledge about the environment external to the institutions, including global student mobility patterns, the economy, the policy arena, and student choice in order to adopt responsive strategies to increase their attractiveness to international students. For example, Arizona State University, which enrolls the 14th-largest number of foreign students nationally, has set up student-exchange and joint-research programs with universities in China and Latin America, in part to develop pipelines for new graduate students. The number of international students enrolled at the university rose $12 \%$ in the following year (Ross, Heaney, \& Cooper, 2007). Thus, as Ross, Heaney, and Cooper (2007) concluded encouraging factors related to international student enrollment can be 
created, learned and improved by institutions to attract more qualified international students to come in.

\section{Push and Pull: Discouraging International Students from Coming in}

The discouraging factors from both the source country and destination country could drive students away from pursuing their higher education in a certain international destination. The major discouraging factors from source country are the fast and robust economic development and the improvement in domestic education opportunities in the source countries (Dollag, 2004; McCormack, 2005). This will in turn open up more opportunities for the source countries to interact with global economic market and create rising employment opportunities (particularly in the science and technical fields) in their own countries (Lee, 2008). Another fact is, in the current world, richer information are better available for students to choose their international study destination before their actual going abroad. Especially the unfavorable stories about international education from internet, public media, and word of mouth from the increasing returning students have deciphered the mystery experience of study abroad and to a certain degree discouraged some potential students to seek for their international education (Buddington, 2002; Bybell, Jackson, \& Ray, 2013).

In the U.S. some major factors are identified as pushing-out factors which discourage international students from coming to the U.S. including the comparatively high tuition fees among other major hosting countries (Mooney \& Neelakantan, 2004; Naidoo, 2007), the weak recruiting efforts by colleges/universities and insufficient government support (Douglass \& Edelstein, 2009). Other likely geopolitical and economic factors may include international sentiments opposed to the U.S. handling of 
the war in Iraq (Lee, 2008); barriers created by the U.S. to limit and monitor "foreigners", such as cumbersome and costly visa procedures (McCormack, Neelakantan, \& Overland, 2007); the financial costs of living in the U.S. (Douglass \& Edelstein, 2009); and perceptions of discrimination against international students, particularly against students form the Middle East after September 11, 2001 (Lee \& Rice, 2007).

\section{Summary of Background Literature}

This literature review discussed three streams of research on the topic of U.S. and its international students in the new global higher education context. The irreplaceable economic, academic and social-cultural benefits of educating international students offer a solid justification for U.S. higher education to further seek effective strategies and policies to attract more desired international talents. The new trends and patterns of competing for international students among the major hosting countries help analyze the current situation and future direction for U.S. higher education to actively maintain and pursue a more competitive status in the global international student market. Research on both the encouraging and discouraging forces for international students from national and institutional levels confirms that multiple factors are working in combinations to affect international student's choice of study destination. In general, the existing literature emphasized the important relationship between the U.S. higher education and its international students. However, there is usually no explicit differentiation of international undergraduate students from the whole student body of international students and thus, few attention has been paid specifically to the subgroup of international undergraduate students in U.S. higher education. 


\section{Theoretical Framework: Demand Theory}

The purpose of this study is to examine whether international undergraduate student enrollment are related to the tuition and fees that institutions charge to them. In domestic studies, student enrollment behavior is generally classified into two groups, micro level studies and macro level studies (Paulsen, 1990). Micro level studies indicate the ways in which environmental, institutional and student characteristics affect a student's choices about whether or not to attend colleges and which college to attend. Macro level studies show us how changes in environmental factors (usually beyond an institution's control) and institutional characteristics (usually within an institution's control) can affect an institution's total enrollment. This group of studies is also referred as student demand studies. These two types of studies offer mutually complementary knowledge bases for enhancing the effectiveness of enrollment planning activities, student marketing and recruitment activities. The focus of this study is to examine one aspect of the micro level factors affecting institutional enrollment, specifically, what do institutional tuition and fees affect international undergraduate student demand of U.S. higher education.

Student demand studies applied in higher education is generally called student demand theory. It offers an important investigation into the economic factors that affect student enrollment based on demand theory in economics. Researchers and practitioners in student enrollment field have agreed student demand study is an important step in the development of a specialized knowledge base for enrollment managers (Heller, 1997; Leslie \& Brinkman, 1987). Hossler (1984) states "to plan for enrollments and to manage enrollments, professionals must begin with an understanding of the demand for higher 
education and of how students decide to enroll in a college or university" (p.8). Therefore, institutions can have a better prediction and control to their international undergraduate student enrollment by understanding the important economic factors affecting the demand of their desired student.

Demand theory in economics is originated from the work of neoclassical economist Alfred Marshall (1949). The theory posits that as the price of a commodity or service changes, the quantity demanded also changes. There are two approaches to such a theory. One approach views the decision to purchase a product or service as an investment decision, while the other views it as a current consumption decision. The investment approach to the theory of demand asserts that an individual will purchase a product if the present value of the expected stream of benefits resulting from the purchase exceeds the present cost of the purchase. The consumption approach considers the buyers' evaluation of the costs of the product or services and their own financial capabilities and preferences at certain time periods. This implies the importance of "imperfections" in buyers' behavior need not be overlooked (Buckley, 1996). Any factors that lead buyers to make the purchase or spend more for a given item than necessary, are important factors to consider when estimate the demand of a product or service. Among others, Leslie and Brinkman (1987) summarize the student demand for higher education is affected by the cost of attendance, the financial ability of students, and students' preferences.

Research on U.S. domestic student demand studies has a well-established tradition. Ostheimer's (1953) was the first reported study assumed that the enrollment in a state was a function of tuition and fees, state per capita income, educational attainment, and the 
geographical proximity of higher education institutions to the population. Jackson and Weathersby (1975) reviewed seven major studies at the time and calculate standardized values of Student Price Response Change (SPRC) and concluded that a $\$ 100$ price increase was associated with roughly a one percent point decline in the participation rate among the 18-24 year-old population. Leslie and Brinkman (1987) synthesized 25 studies conducted between 1967 and 1985 and calculated the average SPRC ranged from -0.2 to -2.4. After Leslie and Brinkman review, newer studies kept helping to shed light on the question of how sensitive higher education enrollment are to increases in tuition (Heller, 1997). Especially, many focused on the effect of tuition and aid changes on students of different income categories, races, and in different college sectors (Heller, 1997). The main interest of many of these studies was to measure price elasticity of demand for higher education. The general consensus of these studies is that the demand for higher education can be influenced by various factors and tends to be elastic for certain groups of students and institutions but not to others.

A subset of student demand studies explored the institutional factors that affect student decisions for college. Although different terminology was used, findings were quite consistent with each other. For example, Lewis and Morrison (1975) found 6 characteristics most frequently utilized by college applicants to consider the attendance of a specific institution including cost, location, size, general reputation, and distance from home. Leslie, Johnson, and Carlson (1977), and Murphy (1981) found similar results based on surveys of students at high schools by asking them to rank the most important college attributes to their decision of college attendance. Other subsequent studies continued this trend and focused primarily on the impact of pricing, institutional 
reputation, and distance on students' decision to attend a higher education institution (Cooke \& Boyle, 2011; Litten \& Brodigan, 1982; Mixon, 1992). Paulsen (1990) further added a list of several specific institutional characteristics that may affect student's decision making: percentage of in-state students, percentage of part-time students, percentage of degrees conferred in liberal arts fields, admission selectivity, and urban versus rural location, completion, direct costs of college, curriculum.

The findings of these studies suggest that undergraduate student decisions are affected by some of the major factors, namely, price/cost/financial aid, income, and other descriptive institutional characteristics including control, level, geographic location, etc. In general, the existing literature is still very limited in its ability to provide a comprehensive understanding of demand of international students. Furthermore, there has not evolved at the international undergraduate level working hypotheses or theories regarding their enrollment demands. However, a closer examination of the demand studies by three classified groups into price, student financial ability, and student preferences aligned with Leslie and Brinkman's (1987) demand theory model could provide a more structured estimation to specific factors determining international undergraduate student's choice of attendance in U.S. higher education institutions.

\section{Price of Higher Education Institutions}

During the past decades, U.S. higher education has endeavored to preserve college access while at the same time steadily increasing costs (Ehrenberg, 2000). Students are sensitive to a range of cost issues apart from and including tuition and fees (Doorbar, 2001; Joseph \& Joseph, 2000; Mazzarol \& Soutar, 2002; Waters, 2006). Geiger (2004) noted that the escalation of tuition prices was the most persistent public 
concern about higher education from the mid-1980s through the 1990s. Today, understanding the relationship between tuition price and student enrollment continues to be a concern for scholars and policy makers in the field of higher education. Especially, recent reductions in state appropriations to higher education have led many institutions to significantly increase tuition in an effort to bolster revenue. The key concept of demand theory posits that the quantity of a product or service supplied or demanded is related to its price. There is an inverse relationship between price and quantity demanded. When price increases, demand decreases, and vice versa. There is a significant body of research in higher education agrees with this relationship between college enrollment and price and most price elasticity estimates come from demand functions using tuition (Fethke, 2011; Heller, 1997, 1999; McPherson \& Schapiro, 1991; Winston, 1999).

However, some studies found, under certain circumstances, demand of higher education to be relatively insensitive to tuition (Levine et al., 1988; Paulsen \& Pogue, 1988; Quinn \& Price, 1998). In two empirical studies including both public and private institutions, positive relationships were identified between nonresident tuition and enrollment levels (Dotterweich \& Baryla, 2005; Mixon \& Hsing, 1994). Later, Shin and Milton (2006) examined enrollment effects specifically at public universities and colleges by using in-state tuition levels from 1998 to 2002 to estimate the impacts of tuition increases on enrollment growth and concluded enrollment changes were not affected by changes in tuition or financial aid over the three-year period. Another recent empirical finding derived from Hemelt and Marcotte's (2011) work was that despite the increases in the rate of real tuition growth, there is no evidence that the tuition elasticity of enrollment at public 4-year institutions has increased. Their estimates suggest that tuition 
can be used as a lever to offset revenue losses from declining appropriations.

In general, this group of research focused on price elasticity and college enrollment has addressed the effect of tuition increases on enrollment, the degree to which students are "price sensitive" in making the decision to attend higher education institutions. It indicates that owing to the competition of similar educational offerings in higher education, students have become more and more price sensitive and tend to make informed decision before making their college choices. Taken together, this body of literature suggests that price sensitivity is a key variable in predicting student enrollments and an essential concern for policy makers and institutional leaders seeking to increase college access by those in various demographic cohorts. However, there exist some different degrees of price elasticity between in-state and out-state students (Curs \& Singell, 2002). Also, although the overall the price elasticity of out-of-state student enrollment is inelastic (i.e., a one percent increase in nonresident tuition is associated with less than one percent decrease in nonresident enrollment) there is substantial variation among different types of institutions (Zhang, 2007). For example, less competitive institutions are more likely to suffer a large reduction in enrollment when out-of-state tuition increases.

Although research has largely focused on domestic education, it seems reasonable to assume that the results are also relevant for the demand of international education. International students are also found price-responsive, but may not as price-responsive as domestic students in the same way because international students tend to have different expectations of investment return than domestic students (Agarwal \& Winkler, 1985). Some research implies that owing to omitted preference variables there might appear 
positive correlation between tuition and demand (Dreher \& Poutvaara, 2010). For example, increased financial aid to international graduate students could be one factor that triggers out the increase of international student enrollment to the U.S. higher education institutions, and an improvement of the U.S. institutions' ranking around the world could be another (Borjas, 2004).

In addition, students and their families might regard tuition as an indicator of institutional quality (Zhang, 2007). Thus, an increase in tuition and fees might actually raise the perceived prestige of the institution, hence boosting student demand. Also, considering the decreased state funding in higher education in recent decades and the revenue-generating function of international enrollment at public institutions, an institution might increase both the international tuition and its enrollment spaces for international students, resulting in a positive correlation between tuition and enrollment. Nevertheless, it is not clear in the literature whether institutions have a pre-determined quota for international student enrollment or they fill totally based on demand. For the purpose of this specific study, it is hypothesized that in general, as price increases, demand from international undergraduate students may not decrease. However, this relationship could be moderated by institutional types.

\section{Student Financial Ability}

In demand studies focused on domestic students, financial aid and student family income are always the two important factors related to the price of attending an institution. For financial aid factor, student demand theory suggests enrollment positively associated with amounts spent on financial aid (Leslie \& Brinkman, 1987). Many studies on domestic students have examined changes in financial aid packages to estimate the 
enrollment impact of the costs of higher education. For example, Kane (2003) examined the Cal Grant aid program in California using data from 1998 and 1999 and found that receivers of the financial aid program were more likely to enroll in college than nonreceivers. Dynarski $(2000,2003)$ examined evidence from both the HOPE scholarship program in Georgia and the elimination of the Social Security Student Benefit Program in 1982. She found each $\$ 1,000$ increase in financial aid to be associated with an increase in the college attendance rate of about 4 percentage points.

Student family income is another important variable in domestic demand studies. For domestic students, the ability to afford the cost of undertaking higher education is a critical element in the decision of whether to attend higher education. This is increasingly a relevant factor as higher education becomes more commercialized thereby putting greater pressure on students to become increasingly self-supported (Guruz, 2011). Research has shown that low income students are associated with lower expectations about educational attainment and take college entrance examinations less frequently compared to their high income counterparts (Carter, 1999; Engberg \& Allen, 2011). Only $40 \%$ of low income students enroll in a postsecondary institution immediately upon high school graduation versus $84 \%$ of those students with family incomes over $\$ 0.1$ million (Fitzgerald \& Kane, 2006). As a result, students from relatively wealthy families are more likely to attend college (Astin, 1972; Clarke, 2007; Cummings, 2001) and there is a significant difference in price sensitivity to higher education between low income and high-income youth (Kane, 2004; Paulsen \& St John, 2002).

However, financial aid and student family income factors are not working the same way when students pursue international higher education. For example, Agarwal and 
Winkler (1985) estimated international student demand in Asian, Mediterranean, and Mideast nations for U.S. higher education and found out student family income is not a significant factor affecting international graduate student demand for U.S. higher education since many international graduate students receive financial support from various external sources. For financial aid factor, with the fact that there are very limited financial aid programs opening to international undergraduate students before their actual enrollment into the institution, more than $82 \%$ of international undergraduate students are paying full tuition fees in U.S. higher education upon their enrollment. For the influence of student's family income, even though there are large differences in college enrollment among those international students with different family incomes, the evidence does not necessarily imply that family income is the major constraint preventing their international college enrollment since students and their families might consider more than just gaining academic benefits from the international education (Douglass \& Edelstein, 2009; Naidoo, 2010; Scott, 2007). Thus, financial aid and family income factors may be considered differently when investigate international undergraduate students enrollment.

The anticipated great economic and other social cultural benefits have convinced students to pursue international higher education even though they do not have promising financial aid or have low family income which is different from the situation of U.S. domestic students. While some recent researches have focused on the economic return of international studies (Lange, 2012; Lowell, Bump, \& Martin, 2007; Tremblay, 2002), others emphasized the importance of the social capital which international students gain on a globalized job market (Aguilera \& Massey, 2003; Perna, 2006). Bourdieu's (1986) concept of "cultural capital" was one of the early important explanations to this 
phenomenon. It has been argued that for middle class parents financing the international education of their children presents an opportunity to obtain "a scarcer more valuable type of cultural capital in the form of a Western university degree" (Waters, 2006, p.188). The symbolic potency of international education is fully realized following the students' return home, giving them an advantage in the labor market relative to locally educated youth (Bourdieu, 1986). As a consequence, international education may play a part in the reproduction of social class. Cultural capital, or tacit knowledge, as Williams (2007) has described, built up through international education, when followed by return migration, creates an elite of "overseas educated locals" that form a powerful faction of Sklair's (2001) transnational capitalist class.

In addition, there is no systematic reliable data available about the amount of financial aid international undergraduate student received from U.S. institution and the impact of the financial aid to the enrollment of those students. This fact prevents related studies from considering financial aid as a factor to understand international undergraduate student enrollment in U.S. higher education. Likewise, there is no internationally comparable data collected for measuring international student's family income. Although some studies try to use nation's per capita income to estimate international students' financial ability of pursuing international higher education (Wobbekind \& Graves, 1989), differences in nations' per capita income do not reflect the capacity of wealthy elites to pay for education in the U.S. Thus, neither financial aid nor family income would be considered as predicting factors for international undergraduate student enrollment in this study. 


\section{Student Preferences: Institutional Type and Quality}

Prior research has identified and confirmed that there are a number of preference factors that students consider when determining to attend a particular university (Soutar $\&$ Turner, 2002). These preferences may related to institutional characteristics including the academic reputation of the institution, the range of academic programs, the campus atmosphere, the quality of the teaching staff, and the type of university, etc. Also, the preferences may include various more personal factors related to each individual student's characteristics. In recent decades, student's preferences have gained more consideration in student demand studies because the idea of students as consumers is gaining popularity in higher education discourse. This idea shift turns students into an important client or even partner of the university (Oprean, 2007) and legitimizes students as the central driving force in higher education development through their perceived purchasing power. Thus, borrowing form the economic sector, the marketing concept for educational institutions suggests that a college can achieve its goals most effectively by considering the preferences of potential students (Litten, Sullivan, \& Brodigan, 1983).

The preferences of international undergraduate students have also begun to attract more attention from higher education researchers and practitioners. According to the economic concept of market segmentation, a market segment is a group of people who have characteristics, behavior, desires, needs, perceptions, or other phenomena that are similar within the group but are distinct from the rest of the market or from other groups in the market (Litten, Sullivan, \& Brodigan, 1983). International undergraduate students can be considered as a market segment according to their unique characteristics which differentiate them from domestic students and international graduate students. Whatever 
factors are involved in determining an international student's preference, some factors should be more important than others. In the literature, institution type and another three closely related terms, institutional quality or prestige or image, although defined differently in various respects, are overwhelmingly identified by the majority of research (or potential applicants) to be the most important preferences when choosing a higher education institution to attend.

Institution type is commonly cited as an important preference criterion that most students make their college decisions. Owing to the diverse representation of institutions with various missions and purposes, the classification of higher education institutions into different types by levels and controls is a convenient means to allow students make more relevant choices. Previous research has proved the importance of institutional type as a criterion for the college choice decision of U.S. domestic students (Austin, 1988; Baker, Creedy, \& Johnson, 1996; Noorani \& Abolghasem, 1980; Pyvis \& Chapman, 2007; Zikopoulos \& Barber, 1986). There is also evidence showing that international student enrollment in a U.S. higher education institution may also be influenced by its institution type. For example, international student enrollment may vary from public to private institutions and from two-year to four-year institutions (Douglass \& Edelstein, 2009). In the CGS survey (2010) international applications increased 6\% at public, doctoral institutions and $12 \%$ at private, not-for-profit doctoral institutions. At master's-focused institutions, international applications fell $22 \%$ at public institutions and dropped $10 \%$ at private, not-for-profit institutions. However, little is understood as to how the differences among various types of institutions affect their student enrollment from the perspective of international undergraduate students. Therefore, a hypothesis this study is going to test is 
whether international undergraduate student enrollment in a U.S. higher education institution is related to its institution type.

Studies about institution quality (and reputation or image) confirmed that perceived good quality can strongly influence student's decision to attend an educational institution (Baryla \& Dotterweich, 2006; Bourke, 2000; Gutman \& Miaoulis, 2003; Mazzarol, 1998; Soutar \& Turner, 2002). Quality (and reputation or image) has also been specifically proved to be important in international student's preferences when choosing their study destination. Research (Austin, 1988; Baker, Creedy, \& Johnson, 1996; Noorani \& Abolghasem, 1980; Pyvis \& Chapman, 2007; Zikopoulos \& Barber, 1986) shows that the primary reason students come to the U. S. for higher education degree programs is their belief that they could receive high quality education. Outside of the U.S., institutional quality (and reputation or image) is also identified as one of the most important determinants of university preference for international students considering enrolling in Australia universities (Mazzarol \& Soutar, 2002) and Malaysian Private Universities (Padlee, Kamaruddin, \& Baharun, 2010). Usually, it is admitted that the attractiveness of college increases with the measure of quality and reputation.

However, there is considerable question about what makes for quality in higher education. Previous research offers a number of possible answers to this question based principally on contemporary attributes of individual universities. The earliest of these studies by Astin and his colleagues indicate that institutions with large enrollments and high SAT/ACT averages for entering freshmen receive the greatest prestige and tend be perceived as high quality institutions. The more recent studies have generally confirmed these findings and expanded them by additionally finding that institutional quality 
correlate significantly with the following variables: average high school class standing of entering freshmen, admissions acceptance rates, instructional budget per degree, percentage of faculty possessing Ph.D.'s, faculty publication rates, and retention/graduation rates. In summary, prior research suggests a common approach to measuring quality in higher education is emerging. It divides the measures into input, process and output measures (Gormley \& Weimer 1999; Pascarella, 2001) or simply called input-process-output (IPO) model by Volkwein and Sweitzer (2006).

First, research suggests that one of the leading determinants of a good quality institution is the quality of its incoming students or the quality of its inputs (Dill \& Soo, 2005). The measure of inputs usually includes the admissions selectivity and institutional size (Astin, 1972; Astin \& Lee, 1972; Astin \& Solomon, 1981; Grunig, 1997; Porter \& Toutkoushian, 2002; Schmitz, 1993; Solomon \& Astin, 1981; Volkwein, 1989). The size of the institution, usually expressed as total student enrollment or total faculty size (Graham \& Diamond, 1997; Volkwein, 1989). The general expectation is that larger universities have better achievements and reputations. For example, Graham and Diamond (1997) observed that public research universities are especially dependent on large enrollments to build the critical mass of faculty and graduate students necessary to support ambitious programs of research and graduate study. Admissions selectivity is indicated by measures such as median ACT/SAT score, freshmen in the top 10\% of high school class, and admissions acceptance rate.

Second, measures of the quality of teaching and student learning processes are generally not very many. The mostly cited variables are the quality of the faculty. Quality of faculty is very important indicator of the quality of a higher education institution. Blau 
(1994) provides evidence high quality faculty attract high quality students. Therefore, successful faculty recruitment and student recruitment interact with each other. It is likely that faculty instructional and academic service activity exerts a great influence on current students; and faculty research and scholarship exerts a great influence on perceived faculty quality and academic reputation. Both sets of faculty activity increase the attractiveness of the institution to prospective students, eventually strengthening enrollment and financial resources.

Several authors have used average faculty salaries as foundational indicators of faculty talent and institutional quality (Adams \& Krislov, 1978; Brown, 1967; Grunig, 1997). Other authors have used faculty publications and research activity as indicators, but an array of studies has demonstrated that the total number of faculty publications and the total amount of research funding is more an indication of faculty size than of faculty productivity (c.f., Graham \& Diamond, 1997; Toutkoushian, et al., 2003). Thus, most investigators now use per capita publications and per capita research dollars as better indicators of research and scholarly productivity (Volkwein \& Grunig, 2005; Zheng \& Stewart, 2002). In any case, our conceptual model assumes that the recruitment of talented faculty via salaries produces faculty research and scholarly productivity, however it is measured.

The most obvious and widely cited explanation for financial capability contributed to institutional quality is that the higher the financial resources of an institution, the higher its scholarly achievements and prominence (Bowen, Kurzweil, \& Tobin, 2005; Volkwein, 1989). On the one hand, it assumes that more financial resources enable the institution both to buy more faculty members to increase the faculty/student ratio since 
high faculty/student ratio since in theory a higher faculty/student ratio has a positive impact on instructional quality (Volkwein \& Sweitzer, 2006). On the other hand, higher financial capability can make sure institutions pay faculty members higher salaries, thus, raising faculty quality by hiring the best full-time and adjunct faculty that are available in the marketplace. In turn, higher faculty compensation has a positive impact on research and scholarship. Spending on student recruitment activity and support services positively influences the relative attractiveness of the institution to prospective students (Szelest, 2003).

Third, prior research on output measures is also limited, with an emphasis on retention rates, graduation rates, and employment prospects of graduates. Graduate employment measures are attractive output measures, but these indicators are not very applicable to international undergraduate students since the majority of them will not be able to pursue an employment in the U.S immediately after they graduate like a lot of international graduate students (holding Master's or $\mathrm{PhD}$ degrees) owing to visa and other restrictions. If they tried to find a job in their own source countries or outside of the U.S., it is hard to collect and verify the validity of the information. Thus, the primary output measures appropriate for international undergraduate student studies could be the retention rates and the graduation rate.

\section{Summary of Theoretical Framework}

In this section, student demand studies are discussed to offer a theoretical framework for examining the effects of price change on international undergraduate student enrollment in different types of U.S. higher education institutions. Research on U.S. domestic student demand studies has a well-established tradition. Many studies have 
explored the institutional factors including price/cost/financial aid, student family income, and other institutional type related characteristics and the relationship of these factors to domestic student enrollment. In general, this group of research indicates price of institutions, student financial ability, institution type, and the quality/reputation of the institution can be important predictors for domestic college student enrollment. However, these factors may influence international undergraduate student enrollment differently from the U.S. domestic students owing to the unique characteristics of international undergraduate students. In the end, this section proposes its application of the modified student demand theory to be an appropriate theoretical framework for the research of international undergraduate student enrollment in U.S. higher education. 


\section{CHAPTER THREE: RESEARCH METHODOLOGY}

The purpose of this study is to examine how tuition changes affect international undergraduate student enrollment at U.S. higher education institutions. This study will adopt a quantitative research design by using the national representative large-scale data system of Integrated Post-secondary Data System (IPEDS). The two research questions this study asks are:

1) Is international undergraduate enrollment related to the changes in institutional out-of-state tuition and fees?

2) Is the relationship between international undergraduate enrollment and out-ofstate tuition and fees moderated by institutional type?

The choice of the research method is guided by two research objectives. The primary objective is to estimate the tuition sensitivity of international undergraduate students in U.S. higher education institutions. There is a general assumption that students as consumers of higher education are price responsive to the products or services they receive and international students are likely observing the same economic rules. However, there is no previous research done focusing on how international undergraduate students respond to the increasing tuition and fees in U.S. higher education by using national level longitudinal large-scale data sets. The design of this study is a timely effort to help explore alternative research methods to better understand international undergraduate student enrollment in U.S. higher education.

The second objective of this study is to explore to what extent the impact of tuition change on international undergraduate student enrollment varies at different types of institutions. Owing to the variety in the education and experience colleges and 
universities provide, student enrollment from different types of institutions responses to price change may vary accordingly. During the past decades, international students are found populated in some U.S. institutions but not others. Research has also indicated there are certain institution type related characteristics besides tuition and fees are in function to guide international students' choice of their study destination. Thus, institution type is a good factor to better understand the relationship between tuition and fees and international undergraduate student enrollment in U.S. institutions.

To illustrate how this study will answer the research questions, the rest of this section presents the rationale for the research design, description of data source (Delta Cost Project version of IPEDS), related prior studies using IPEDS, the sample, the data collection procedures, the definition of major variables, analytical strategy, the generalizability and limitations of the study.

\section{Rationale}

A number of previous quantitative and qualitative studies using small samples have examined the institutional factors that influence international student enrollment behaviors. Within the quantitative studies, survey instruments, self-reported questionnaires and developed assessing scales were largely implemented (Buddington, 2002; Chirkov, et al., 2007; Wang \& Mallinckrodt, 2006; Ying, 2005). In the qualitative studies, the techniques of structured or semi-structured in-depth interviews and focus groups were usually adopted by researchers (Cadman, 1997; Constantine, et. al., 2005), supplemented with journal or document analysis (Koehne, 2006; Rhee \& Sagaria, 2004), and single case studies (Kher, Juneau, \& Molstad, 2003). There is also research conducted with mixed methods (Robertson, Line, Jones, \& Thomas, 2000) and online 
questionnaires (Ye, 2006). However, most of the research sampled students within one or two colleges with small samples. The generalizability could be largely limited to the sample size and the students' background like ethnicity, nationality, major specialization, school type and region in the sample.

Another feature of this group of studies is that most used cross-sectional data and conducted descriptive analysis in a single field of study (Chellaraj, Maskus, \& Mattoo, 2008) or on special populations such as women or students of one specific country origin (Cole \& Ahmadi,2003; Joseph \& Joseph, 2000). Some rely solely on single-year data from individual institutional records (McClain, Vance, \& Wood, 1984; Ross, Heaney, \& Cooper, 2007) or on surveys only of students who enrolled at the surveying institution (Malaney, 1984). There were few studies based on international students representing a diverse set of programs, considering time series effects, and examining the hypothesis of a group of variables by applying statistical methods like regressions, path analysis, and ANOVA. There are even fewer studies report results based on multivariate analysis.

This current study makes its contributions to the international student enrollment research by applying statistical analytical models based on large scale longitudinal data sets. It is an effective design of macro-level demand studies (Paulsen, 1990) focused on the relationships between the enrollment behavior of student groups and specific institutional characteristics. Previous studies have indicated that using large scale longitudinal data sets to study student as groups is beneficial to university administrators and policy makers in the processes of policy formation, environmental scanning, enrollment planning and forecasting (Hossler, 1984). It is admitted that randomized trials are impossible or not appropriate in many educational situations (Zhang, 2010) and the 
use of longitudinal data could better response to the advocate of scientific research in education when examining higher education policy related issues (National Research Council, 2002, 2005; Schneider, Carnoy, Kilpatrick, Schmidt, \& Shavelson, 2007).

In addition, using large scale secondary data sets better serves the research purpose of this study compared with using questionnaire surveys and in-depth interviews. Although studies using extensive questionnaire survey or large set of in-depth interviews to international undergraduate students can provide valuable insights to understand individual student level choice making, using secondary data help shape what is knowable about the research topic at the institutional and national levels, and being far from neutral in the estimation of international undergraduate student enrollment. Nevertheless, national level large scale data sets claim a more extensive representation of some aspects of international undergraduate student as a group than can ever be achieved by a sole researcher engaging in some interviews or surveys. This is a re-statement of Sayer's (1984) realist call for intensive work to be complimented by extensive research.

\section{Data Source}

The data source of this study is the Delta Cost Project version of IPEDS. IPEDS is the primary source for data on higher education research and policy making managed by the U.S. Department of Education, National Center for Education Statistics (NCES). IPEDS is a system of integrated surveys that collects data from all institutions in the U.S. whose primary mission is to provide postsecondary education. Each year, since 1986, more than 6700 institutions including college, university, and technical and vocational institution that participates in the federal student financial aid programs are mandatory to submit the data on various aspects of their institutions. 
IPEDS has been used in a wide variety of applications for institutional research in higher education since last decade, as a comprehensive, national level large scale data system. Some examples of these studies include a report on endowment spending at private colleges (Basch, 1999), trends in institutional minority enrollment and graduation rates (Pavel \& Reiser, 1991), and administrative satisfaction with the governmental regulatory climate in the 1990s (Volkwein, Malik, \& Napierski-Prancl, 1998). There are also prior studies using IPEDS to estimate student demand in colleges and universities. Heller $(1997,1999)$ used IPEDS to examine the relationship between tuition prices, state grants, and public college enrollment in the 50 states from 1976 to 1994 . This study is able to investigate differences in enrollment behavior among Asian American, Black, Hispanic, and White students, as well as among college sectors and establishes policy recommendations for states to improve equality of access to public higher education in the U.S.

Other more recent studies using the IPEDS as data source also achieve various important research purposes in higher education. For example, IPEDS has been used to compare postsecondary institutions by various aspects (Schuh, 2002), examine funding of public institutions (Schuh \& Shelley, 2001), identify relationships between graduation rates and institutional characteristics (Bailey, 2006), examine the effects of part-time faculty employment (Jacoby, 2006), and compare student commitment at two-year and four-year institutions (Strauss \& Volkwein, 2004). In addition, the IPEDS can also be used in some more comprehensive studies that build a classification system for two-year institutions based on variables related to enrollment, student demographics and institutional characteristics (Hardy \& Katsinas, 2006), estimate the standard demand 
equations for nonresident students using national, state, and institutional level data (Zhang, 2007), and recommend practical policies of using community colleges to control college costs (Romano \& Djajalaksana, 2011). In all these studies researchers have explored the various advantages of using IPEDS as data source and justified its effective applicability in higher education research.

The advantage of using Delta Cost Project version of IPEDS is that adjustments have been made to harmonize and standardize the data to account for changes over time in accounting standards and IPEDS reporting formats. Owing to the fact that it is sometimes difficult to make comparisons in higher education over time with definitional changes throughout the years, as well as some major changes in financial reporting standards, the Delta Cost Project commissioned the development of a secondary database to mitigate many of the problems and facilitate the long-term trend analyses with IPEDS. As a result, the Delta Cost Project version of IPEDS is a longitudinal database that includes institutional data on postsecondary finance, enrollment, staffing, completions and student aid for academic years 1986-87 through 2009-10. More importantly, it has translated IPEDS into analytical formats to make them conducive to longitudinal analyses of trends in higher education related to revenues and spending. Thus, this study finds the Delta Cost Project version of IPEDS is an adequate data source for answering the research questions and achieving the research purpose.

\section{Sample}

In order to maximize the generalizability of the study and make the best of the longitudinal feature of IPEDS data, the ideal selected sample should consist of all the four-year not-for-profit institutions that Carnegie-classified offering undergraduate 
degree/certificate and are open to international undergraduate students, located in the 50 U.S. states or Washington D.C. Additionally, international undergraduate students only consist of less than $2 \%$ of all the enrolled undergraduate student body and the crosssectional studies of institution-level data will adversely affected by having too few degrees of freedom. Thus, collecting long time series data could substantially increase the sample size in better estimating the parameters in the statistical model. Therefore, a sample that includes data from 1991 to 2010 (because the information about undergraduate students from foreign countries is available from IPEDS every year since 1991) would best fulfill the expectation of this research.

However, shorter analysis time period has advantages as more variables that align with the theoretical framework and prior empirical research can be included. On the one hand, the theoretical framework of this study indicates that student's decision of enrollment in a specific institution is not only influenced by the price of the institution (including the comparison with the price of other competitor institutions) but also by students' preferences which usually refer to various institution types and other characteristics related to institutional quality or reputation. Based on the literature review, the consistently used variables for measuring institutional quality or reputation are: entry test scores, admissions rate, expenditures, faculty quality, faculty/student ratio, institutional size, retention, and completion. On the other hand, IPEDS started to collect consecutive data for ACT/SAT scores, graduate rates, and expenditures of most institutions since 2002, the total number of application, admission, and enrollment of first-time degree/certificate-seeking undergraduate students since 2003, and the one-year full-time student retention rate for the majority of institutions since 2005 . Thus, a sample 
data start from 2005 to 2010 will better provide controls for the purposes of this specific study.

In addition, the year of 2005, according to the report from the Institute of International Education (Open Doors, 2008), was the first year when international undergraduate student enrollment started to recover and bounce back to its before-911 enrollment level. Between 2001 and 2005, a lot of non-academic and non-economic factors were affecting international undergraduate student enrollment in the U.S. (McCormack, Neelakantan, \& Overland, 2007).Research found out a dramatic decline in the enrollment of international students at U.S. universities in the aftermath of the terrorist attacks of September 11, 2001 since the U.S. tightened its visa-approval process for the sake of national security (McCormack, 2005). Experts in international education agreed that the main reason for the decline of enrollment (2001-2005) was the real or perceived difficulties of getting a visa to the U.S. and expressed concern about the potential impact on the U.S. education system and economy(Lee \& Rice, 2007). Therefore, looking at international student enrollment after 2005 could provide a better data period which allows the research to avoid the immediate influence of the $9 / 11$ event and focus on examining the academic and economic factors affecting international student enrollment in U.S. institutions.

Figures 1-3 created by using IPEDS data set (1991-2010) shows the general trend of international undergraduate student enrollment in U.S. higher education within the 20 years period. Figure 1 shows before 2004, the average total enrollment number of international undergraduate students increased slowly and even dropped significantly after the 911 event in 2001 while during the period of 2005-2010, U.S. higher education 
institutions received a much higher number and faster speed of international undergraduate student enrollment increase than any record in the history.

Figure 1: International Undergraduate Student Enrollment Trend

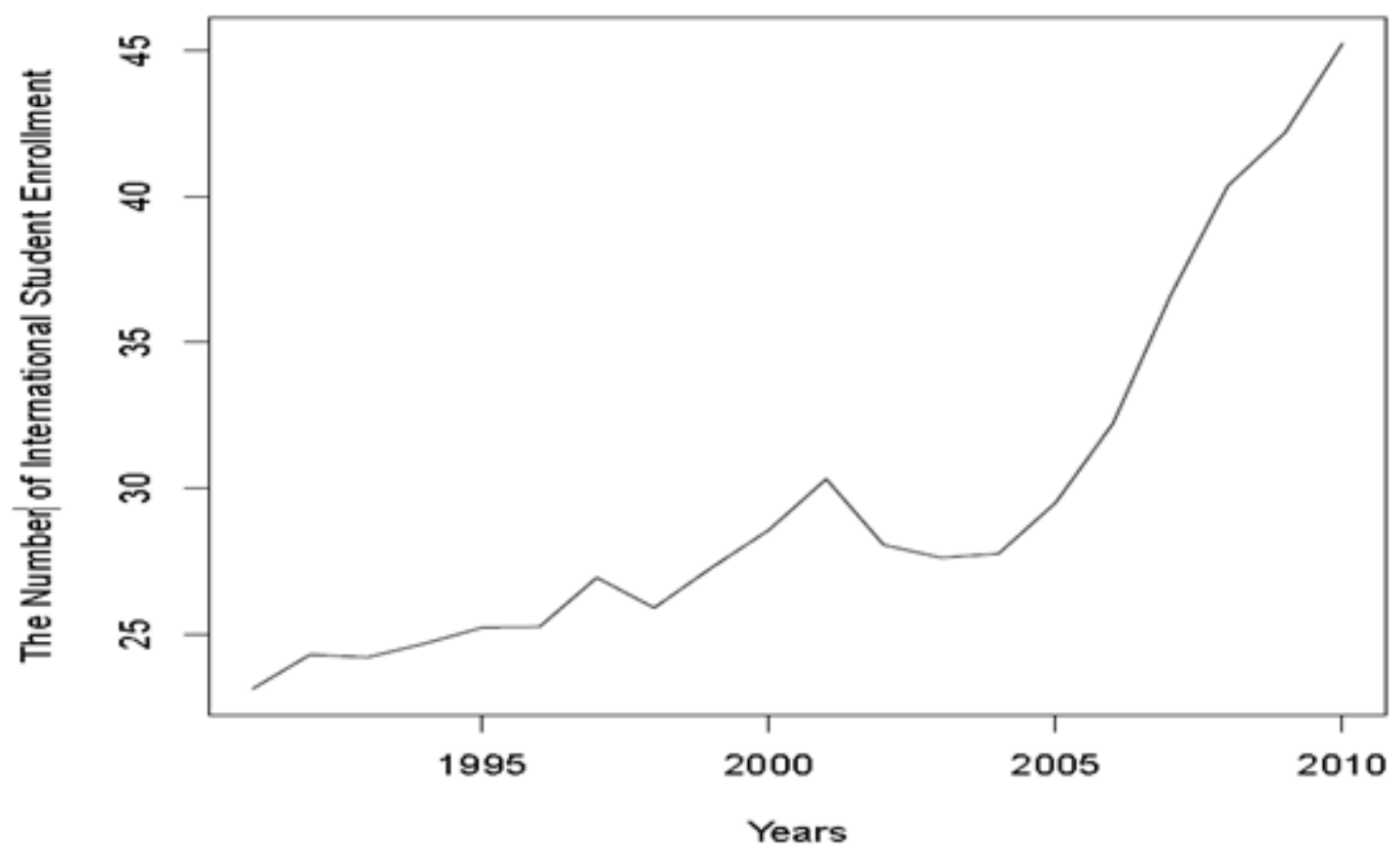

Figure 2 presents the change of out-of-state tuition and fees between 4-year and 2year institutions during the period of 1991-2010. It shows out-of-state tuition and fees among 4-year institutions have been increased continuously and significantly while it stayed stable in 2-year institutions comparatively.

Figure 3 presents the international undergraduate student enrollment in 4-year and 2-year institutions within the same time period and shows that international undergraduate student enrollment in 4-year institutions reflects the national trend of remarkable increase since 2005 while it has a mixed trend in 2-year institutions. These two Figures trigger the researcher's interest to focus on looking at 4-year institutions. 
Figure 2: Change of Out-of-State Tuition and fees between 4-year and 2-year

\section{Institutions.}

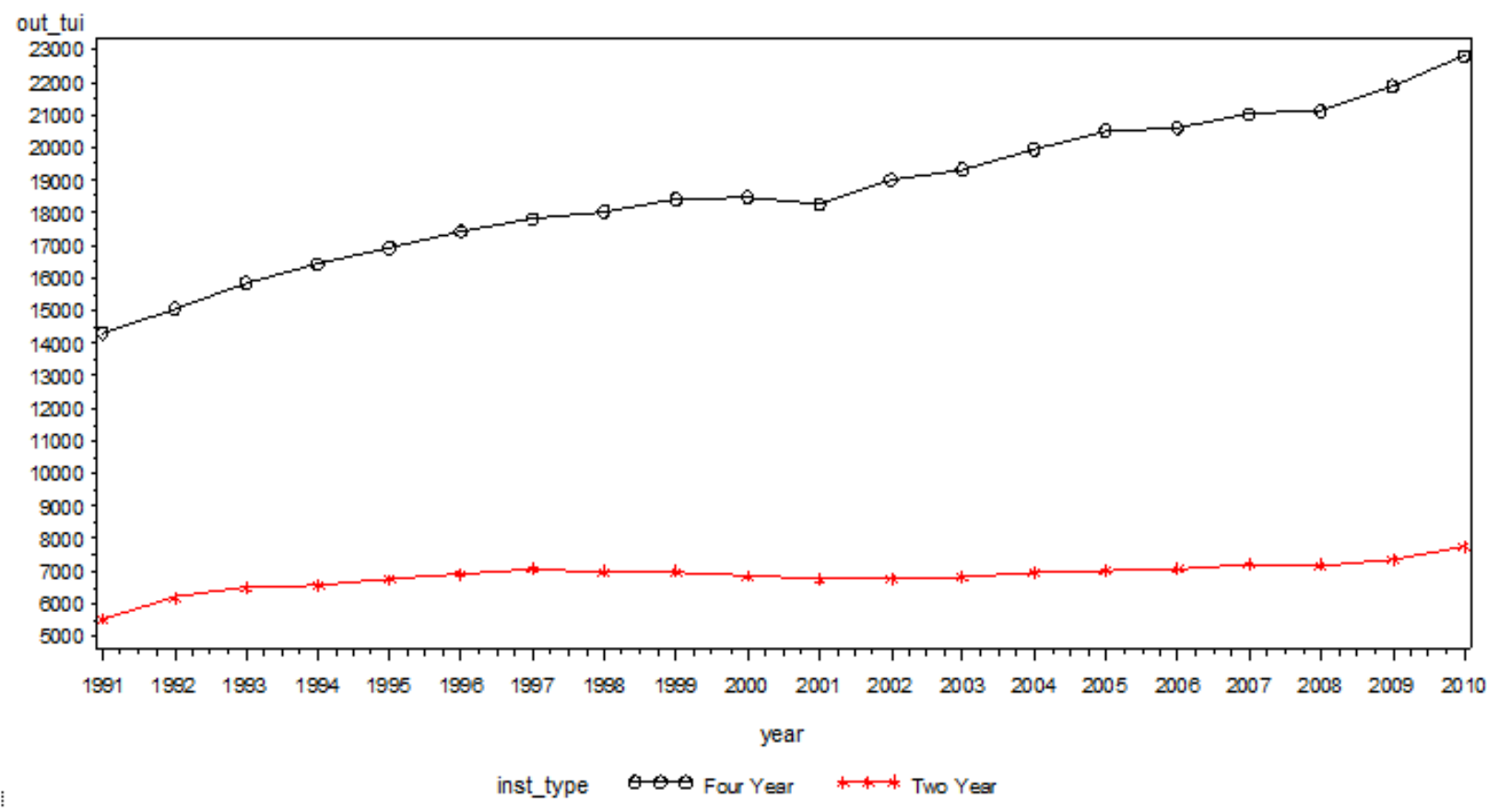

Figure 3: International Undergraduate Enrollment in 4-year and 2-year Institutions

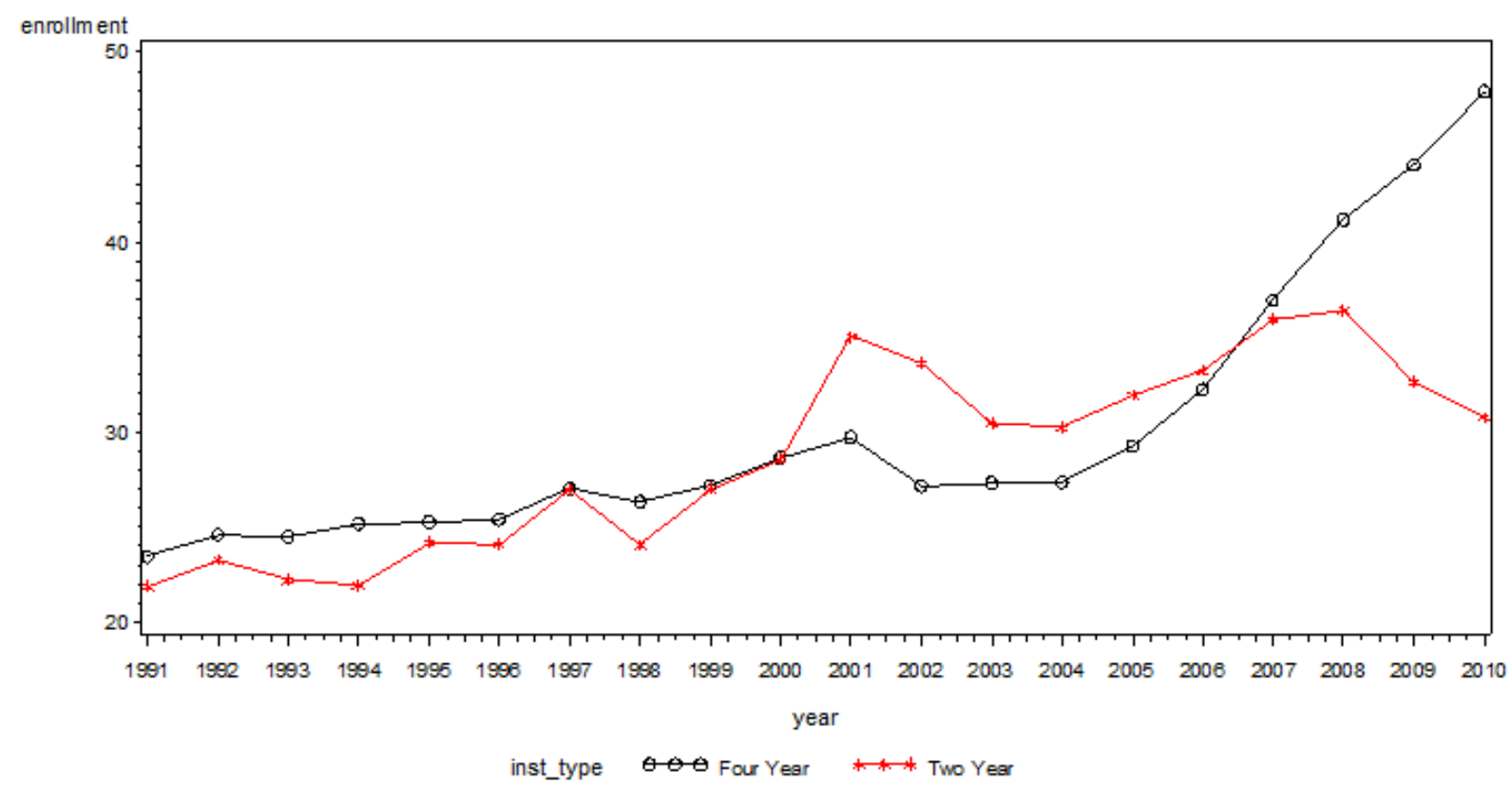


Due to these reasons, the researcher of this study decides to use two samples to conduct the final analysis. The full sample which is the primary sample this study uses would be the 20-year sample consists of those U.S. four-year institutions of both public and private nonprofit controls which report their international undergraduate student enrollment with the period of 1991-2010. Additionally, a shorter sample is also used to represent the same institutions in the full sample but restricted to the period of 2005-2010 by including a richer set of control variables only became available during this recent period. This way, the analysis of the data could not only explore the effect of tuition change on international undergraduate student enrollment across 20 years but also examine a specific range of time when both tuition and student enrollment were found dramatically increased. In another word, the decision of using two samples for the analysis could allow this research better reflect the theoretical framework of the study and better align with prior empirical research on student demand studies.

\section{Data Preparation}

During the data collection, the researcher of this study first collected 20 years (1991-2010) data of required tuition and fees for out-of-state undergraduate students in all the three collapsed Carnegie 2005 institutional types (Doctoral/ Research, Master's, and Bachelor's institutions), an index variable for converting all the 20 years dollar values into 2010 dollar value. Then those variables identified by literature for measuring

institutional quality were added to the data set, including total number of FFTU applicants of the year, total number of admitted FFTU students, SAT/ACT scores, a couple of expenditures variables, education and related expenses per degree, total enrollment of the previous year, total faculty members, faculty/student ratio, retention 
rate, and graduation rate. This first step created a sub-data-set which consisted of most of the major variables used for the analysis and also available from Delta Cost Project. Owing to the missing of measurement about international undergraduate student enrollment in Delta Cost Project, the second step this study took for creating the final sample data set was going to IPEDS data center and collected the total number of firsttime, full-time, degree/certificate seeking undergraduate students who are non-resident alien studying in a four-year institution and created a second sub-data-set from IPEDS data center.

Then, these two data sets were merged into one by a common variable, that is, the unique identification number of each institution by only keeping those institutions which report their international undergraduate student enrollment in the 20 years data period. After performing the needed calculations to the out-of-state tuition and fees and the any variables related to dollar values, like expenditures variables and faculty salaries, etc., to transform them into comparable variables across all years, the final sample consisted of all the variables being used in the final analysis. Then, further imputation and cleaning up was done to obtain a balanced panel data. As a result, there were two sets of samples created: The full sample of 20 years data for 615 four-year not-for-profit institutions, with altogether 12300 observations and a shorter sample of 6 years for the same 615 institutions included in the full sample but with only 3690 observations.

\section{Variable Definitions}

\section{Dependent Variable}

The dependent variable of this study is the total enrollment number of first-time full-time degree/certificate seeking undergraduate (FFTU) students who are non-resident 
alien at a U.S. four-year institution. This variable is downloaded directly from the IPEDS data center. There are not many variables available to measure international student enrollment. Among the few, the FFTU international student was chosen the best group of student to measure international undergraduate student enrollment for this study because FFTU is the major type of international undergraduate students presence in the U.S. higher education institutions comparing with the marginal number of international undergraduate students with other status like transfer, part-time, or non-degree/certificate seeking students owing to the bounding relationship of Visa status to international students degree program studies. Also prior studies indicate FFTU students are more sensitive to prices of attendance (Engberg \& Allen, 2011; Heller, 1997) and more careful to consider certain characteristics related to institutional quality when estimating their

economic return of higher education studies (Lange, 2012; Lowell, Bump,\& Martin, 2007; Tremblay, 2002) before the real enrollment.

\section{Independent Variables}

The independent variables of this study are selected based on the theoretical framework and literature review. For example, based on student demand studies about mostly widely used variable for measuring the cost of attendance (Geiger, 2004) and the unique financial situation of international undergraduate students, the one fixed amount of required tuition and fees for FFTU international students is selected as the key independent variable for measuring the price of their attending a U.S. institution. In addition, based on literature review and discussions on student's preferences in student demand studies (Baryla \& Dotterweich, 2006), a group of control variables are selected for measuring institutional quality. This selection is based on previous studies about the 
quality, reputation, and images, and especially, the so-called input-process-output (IPO) model summarized by Volkwein and Sweitzer (2006). This IPO model includes measures for quality of input (admissions rate, entry test score and size of an institution), quality of process (quality of instruction, quality of faculty, expenditures per degree) and quality of outcomes (student retention rate and student graduation rate).

Required Tuition and Fees for FFTU International Students: This variable refers to the one fixed amount of money charged to an out-of-state full-time undergraduate student by an institution that covers tuition and required fees. The variable comes from the Delta Cost Project Dataset based on IPEDS Institutional Characteristics Survey, which reported data on tuition, fees, and other cost of attending each higher education institution every year. The variable this study chose does not include any estimation of additional or voluntary spending on living, pleasure or personal development costs that related to the degree program study of the students because the lack of reliable data in the data source. Also, it is hard to predict the actual spending of international students while they are in the U.S. since they come from different countries (of various wealth levels) with diverse social economic backgrounds. Another significant difference between international undergraduate student and domestic students is that the majority of international undergraduate students are not qualified for any kind of institutional financial aids before enrolling to a U.S. institution. Thus, there is no need to consider a lot of either need or merit based scholarship or grants as it usually applied to domestic students. Therefore, this required fixed amount of money is the best variable available in the data source which can be used to measure the price of attending a U.S. institution for international undergraduate students. 
Quality of Inputs: This is a vector of three measures: admissions rate, entry test score, and institutional size. The shorter sample will include all the variables mentioned in these vectors while the full sample is only able to include variables measuring institutional size since the admissions rate and entry test scores were not available before 2002 and 2003. Research proves that better quality entering students bring a better peer influence to other students and help creating a better learning and growing environment for all students on campus. Also, high quality student outcomes produced by an institution (which is usually the key indicator for institutional accountability evaluation) is highly correlated with the quality of its entering students.

Admissions rate has been widely used for the average academic ability of an institution's entering freshmen (Astin \& Henson, 1977) and one of the mostly cited indicators for a positive image of an institution (Pascarella, 2001). The measure of admissions rate used in this study is a calculated variable created by using two variables available in the Delta Cost Project: the total number of applicants and the total number of admissions. Educators have a keen interest in admission rate because the folklore of higher education suggests that the more selective institution has higher academic standards than the less selective institution and, by implication, a higher quality educational program. There has been ample evidence suggests that an institution's selectivity is a good measure of its perceived quality (Karabel \& Austin, 1975).

Entry test score is also believed a strong indicator to reflect the quality of its incoming students (Astin, 1972; Dill \& Soo, 2005; Schmitz, 1993). This study uses the median SAT score of admitted students as a measure of entry test score level of an institution. To obtain a single SAT score for each institution, we calculated the midpoint 
between the reported SAT 25th and 75th percentile scores in the IPEDS data set, and used an ACT concordance table to convert average ACT scores into average SAT (Dorans, et., al, 1997; Volkwein \& Sweitzer, 2006).

The size of the institution, usually expressed as total student enrollment or total faculty size (Cole 2009; Graham \& Diamond, 1997; Volkwein, 1989). The general expectation is that larger institutions have better achievements and reputations. For example, Graham and Diamond (1997) observed that public research universities are especially dependent on large enrollments to build the critical mass of faculty and graduate students necessary to support ambitious programs of research and graduate study. In the data source, there are a couple of highly correlated variables could be used to measure institutional size including total enrollment of the previous year, total number of faculty members (full-time and part-time), and total number of degrees awarded. By an initial test, the researcher of this study chose the total enrollment of previous year as the best indicator.

Quality of Process: This is a vector of three measures: quality of faculty, quality of instruction, and the share of institutional education related expenditures. Both the full sample and the shorter sample are able to include all the variables mentioned in this part. In the literature, measures of the quality of teaching and student learning processes are generally not many. Some mostly cited variables are all related to the financial capability of an institution, especially the education related expenditures. The most obvious and widely cited explanation for institutional expenditures contributed to institutional quality is that the higher the expenditures of an institution, the higher its scholarly achievements and prominence (Bowen, Kurzweil, \& Tobin, 2005). Thus, the spending on instructions, 
research, and student service activities could positively influences the relative attractiveness of the institution to prospective students (Szelest, 2003).

Quality of faculty is an important indicator of the quality of a higher education institution. When trying to measure faculty quality, prior research has used faculty publications and research activity as indicators, but more recent studies have demonstrated that the total number of faculty publications and the total amount of research funding is more an indication of faculty size than of faculty productivity (c.f., Graham \& Diamond, 1997; Toutkoushian, et al., 2003). Rather the investment to faculty research activities is recommended as a better indicator of institutional encouragement of research and scholarly productivity to faculty members, and thus, improve the quality of faculty (Toutkoushian, et al., 2003; Volkwein \& Grunig, 2005). However, this indicator is more meaningful in measuring faculty in research-centered institutions, but not for all four-year institutions. Some authors have used average faculty salaries as foundational indicators of faculty talent and institutional quality (Grunig, 1997). For the specific purposes of this study, the variable of average faculty salary is used as a best indicator of faculty quality.

Financial capability, especially the expenditure of an institution is used as an appropriate indicator for the institutions to be able to provide quality education to their students. Prior research indicate that affluent and proper share of spending on research, instructions, and student service activities are all important to enable the institution attract more quality faculty to increase the faculty/student ratio since high faculty/student ratio, in theory, has a positive impact on instructional quality (Volkwein \& Sweitzer, 2006). In turn, higher faculty compensation has a positive impact on research and scholarship. In 
addition, spending on student service activities are also proved exert positive influences to the relative attractiveness of the institution to prospective students (Szelest, 2003).

Therefore, a couple of variables widely used in literature as good indicators for the quality education students receive are chosen to measure the quality of process of an institution. The first variable is faculty/student ratio which refers to the number of fulltime faculty members per 100 full-time students. The second variable is expenditure-perdegree which is selected to be a measure of spending on direct educational costs per degree (in contrast to cost per student enrolled). This is a variable calculated by using education and related expenses (for students) divided by all degrees awarded in the same year. The third variable is the total expenditure of an institution in the current year which measures the general wealthy level or financial capability level of an institution. Then, three more detailed individual expenditures are added to measure if the institution spends more on one aspect than others. These three variables are the instruction share, the research share, and student service activities share of the total expenditures. The last variable used to measure the quality of process this study used is average faculty salary.

Quality of Outputs: This is also a vector of two measures including retention rate and completion rate of every 100 FFTU students at an institution. The shorter sample is able to include both variables but the full sample is only able to include the completion rate variable since the retention rate variable was not available until 2004. Prior studies focused on measuring the quality of outputs in higher education institutions show an emphasis on retention rate, graduation rate, and employment prospects of graduates (Astin \& Solomon, 1981; Dill \& Soo, 2005; Grunig, 1997; Porter \& Toutkoushian, 2002; Schmitz, 1993; Volkwein \& Sweitzer, 2006). Graduate employment measures are 
attractive output measures, but these indicators are not very applicable to international undergraduate students since the majority of them will not be able to pursue an employment in the U.S. immediately after they graduate (like a lot of international graduate students holding Master's or PhD degrees) owing to visa and other restrictions. Admittedly, it is hard to collect and verify the validity of their employment information if they tried to find a job in their own source countries or anywhere else outside of the U.S. Therefore, this study is not able to include employment prospects of graduates as a measure for quality of outputs of an institution.

However, the other two measures available in the data source of this study, both retention rate and completion rate, are also widely used as strong indicators for the quality of an institution. The variable for measuring retention rate used in this study refers to the percent of the previous year's fall first-time full-time cohort (minus exclusions) that re-enrolled at the institution as either full-time or part-time the following fall. The variable for measuring completion rate used in this study refers to the percentage of completions in every $100 \mathrm{FFE}$ students each year. The adding of these two variables to the final model of this study will greatly help provide further explanation to whether perceived quality of the institutional outputs has impact on international undergraduate student enrollment at the institution.

\section{Analytical Strategy}

The statistical analysis of the data is conducted by a using fixed effects regression model. Fixed effects regression is an efficient way to capture time effects and allow for multiple observations for each unit of analysis and compares a unit of analysis to itself (Cellini, 2008). As we know, international student enrollment is a complex decision 
process which might be affected by many factors apart from price and other variables we have selected in this study. Theoretically, no matter how many variables researchers control for, some key covariates which may be difficult to measure might be omitted. However, by using fixed effects method, it is possible to control for all possible characteristics of the institutions in the study, even without measuring them, so long as those characteristics do not change over time. Also, in a fixed effects model, the unobserved variables are allowed to have any correlations whatever with the observed variables. When institutional fixed characteristics are included in the model to control for institution-specific factors, the likelihood of omitted variable bias due to unobserved time-invariant variables is minimized (Schneider, et al., 2007). Thus, the major attraction of fixed effects methods in this research is the ability to control for all stable characteristics of the individual institutions in the study, thereby eliminating potentially large sources of bias.

During the analysis step, for ease of interpretation, this study will use a log-log specification. The fixed effects regression model used in this analysis is described as the following:

$$
\operatorname{Ln}\left(\mathrm{EN}_{i t}\right)=\mathrm{a}+\mathrm{b}_{\mathrm{T}} \operatorname{Ln}\left(\mathrm{T}_{i t}\right)+\mathrm{b}_{\mathrm{I}} \operatorname{Ln}\left(\mathrm{I}_{i t}\right)+\mathrm{b}_{\mathrm{P}} \operatorname{Ln}\left(\mathrm{P}_{i t}\right)+\mathrm{b}_{\mathrm{O}} \operatorname{Ln}\left(\mathrm{O}_{i t}\right)+\mathrm{a}_{i}+\mathrm{a}_{t}+\mathrm{e}_{i t}
$$

Where:

$\mathrm{EN}_{i t}$ is a measurement of total enrollment number of international FFTU student at a four-year institution $i$ in an academic year $t$.

$\mathrm{T}_{i t}$ is the key independent variable, a measure of out-of-state tuition and fees charged to international undergraduate students attending institution $i$ in year $t$.

$\mathrm{I}_{i t}$ is a vector of three measures for the quality of inputs including admissions rate, median of SAT score, and total enrollment of previous year at an institution $i$ in year $t$. 
$\mathrm{P}_{i t}$ is a vector of a couple of measures for the quality of process including faculty/student ratio, total expenditures, share of instruction, research, and student services respectively, and expenditure per degree at an institution $i$ in year $t$.

$\mathrm{O}_{i t}$ is a vector of two measures for the quality of outputs including retention rate and graduation rate at an institution $i$ in year $t$.

$\mathrm{a}_{i}$ is institution-specific fixed effects.

$\mathrm{a}_{t}$ is year effects.

$\mathrm{e}_{i t}$ is the model error clustered at the institution level.

The data will be analyzed using the 9.2 version of SAS which is one of the most convenient and powerful computer software programs for statistical analysis in educational research field. The descriptive statistics will show the general trend and comparison of the change in both international undergraduate student enrollment and the out-of-state tuition and fees in various types of institutions. The fixed effects regression analysis will estimate the tuition elasticity of international undergraduate student enrollment during the full sample data period (1991-2010) and the shorter sample period (2005-2010) and examine whether institution type is an important factor that could moderate the relationship between international undergraduate student enrollment and the change of out-of-state tuition and fees.

\section{Summary}

This Chapter explains the quantitative research design of the study. The data source is the Delta Cost Project version of IPEDS which has been widely used as a reliable and effective data source for higher education research. By collecting its sample from this large scale national level database, this study overcomes the weakness of previous quantitative and qualitative studies that adopted small student samples and limited to a small number of institutions. The dependent variable of this study is the total 
number of international undergraduate student enrollment at a four-year institution. The independent variables are the out-of-state tuition and fees charged by an institution, and three vectors of variables for measuring the quality of institutional inputs, process, and outputs respectively. For the analytical strategy, fixed effects regression will be used to analyze the sample data. The analytical results will show if the change of out-of-state tuition and fees charged by the institution has impact on its international undergraduate student enrollment controlled by various student preference variables related to institutional quality. In addition, if this impact is moderated by different institution types. At the end, limitations about both the data source and analytical model are discussed. 


\section{CHAPTER 4: RESEARCH RESULTS}

The purpose of this study is to examine how out-of-state tuition and fees affects international undergraduate student enrollment at U.S. four-year institutions. The two research questions this analysis aims to answers are:

1) Is international undergraduate enrollment related to changes in institutional out-of-state tuition and fees?

2) Is the relationship between international undergraduate enrollment and out-ofstate tuition and fees moderated by institutional type?

As mentioned in Chapter 3, this chapter presents descriptive and inferential analysis based on two sample datasets. The primary dataset is the 20 -year whole sample from the Delta Cost Project (1991-2010). Then, due to exceptional and unprecedented increases in both international undergraduate student enrollment and tuition and fees at U.S. higher education institutions between 2005 and 2010 combined with the availability of much richer variables in this period, this study added a second analysis based on the shorter sample (2005-2010).

This chapter presents findings separately by sample. For each sample, the following analyses are presented. First, the chapter presents descriptive statistics on the variables used in the analysis and the means comparison of different institution types. Second, the fixed effects regression analysis presents estimates of the tuition elasticity of international undergraduate students in U.S. four-year institutions and compared the differences of tuition elasticity in various institution types during the sample period. Finally, there is a summary of the major results from this Chapter based upon findings from both samples. 


\section{Full Sample Analysis (1991-2010)}

\section{Descriptive Statistics}

Table 1 presents the descriptive statistics of all the variables used in this sample. Based on the sample of 615 four-year institutions which report their international undergraduate student enrollment during 1991-2010, this study contains a total of 12,300institution-year observations. The mean of international undergraduate student enrollment (enrollment) is 31 , representing approximately $1.2 \%$ of the representative total student population. The mean of out-of-state tuition and fees (tuition and fees), charged by institutions to international undergraduate students, is $\$ 18,917$, representing approximately $125 \%$ of the average tuition and fees charged by those institutions to instate undergraduate students.

\section{Table 1: Descriptive Statistics of Variables (Full Sample)}

\begin{tabular}{llllll}
\hline \multicolumn{1}{c}{ Variable } & $\mathrm{N}$ & Mean & SD & Minimum & Maximum \\
\hline Enrollment & 12300 & 31 & 48 & 0 & 798 \\
Tuition and fees & 12300 & 18,916 & 8,269 & 502 & 47,278 \\
Last year enrollment & 12300 & 10,843 & 15,209 & 150 & 244,273 \\
Total faculty number & 12300 & 1,172 & 1,934 & 11 & 25,644 \\
Faculty/student ratio & 12300 & 6.13 & 3.14 & 0.16 & 50.52 \\
Instruction share & 12300 & .52 & .11 & .01 & 1.00 \\
Service share & 12300 & .12 & .05 & .003 & .34 \\
Cost per degree & 12300 & 82,236 & 48,160 & 181 & 561,177 \\
Average faculty & 12300 & 49,263 & 36,574 & 99.46 & $2,610,347$ \\
\hline
\end{tabular}


salary

$\begin{array}{llllll}\text { Cost per student } & 12300 & 24,598 & 21,714 & 53.44 & 305,192 \\ \text { Completion rate } & 12300 & 25.14 & 6.34 & 3.59 & 78.73\end{array}$

Note: All monetary values are expressed in 2010 values. The analytical sample includes a total of 615 institutions.

Since the characteristics of U.S. higher education institutions vary vastly from one to another, institutions with similar characteristics are usually classified into different types for the convenience of analysis. The student enrollment trend may also differ from one type of institution to another. Thus, it is necessary to look more closely to the description of the major variables by different institution types. Therefore, two additional tables are added to give a fuller picture of descriptive statistics of the sample. Table 2 presents the means comparison of variables by Carnegie (four-year) institution types (Research/Doctoral, Master's, and Bachelor's). Table 3 presents the means comparison of variables by control of the institutions (public and private).

Table 2 shows there are remarkable differences of both international undergraduate student enrollment and out-of-state tuition and fees in various institution types. Generally speaking, Doctoral/Research institutions tend to host larger number of international undergraduate students $(M=56)$ than Master's institutions $(M=19)$ and Bachelor's institutions (Mean=16). For the required out-of-state tuition and fees charged to international students, among the three Carnegie categories, Bachelor's institutions charge the highest tuitions/fees to international undergraduate students $(M=\$ 22,800)$, followed by Doctoral/Research institutions $(\mathrm{M}=\$ 19,926)$. It turns out Master's 
institutions charge the lowest tuition and fees $(M=\$ 15,491)$ to international undergraduate students compared with other two institution categories.

Table 2: Descriptive Statistics of Variables by Carnegie Institution Type (Full Sample)

\begin{tabular}{|c|c|c|c|c|c|c|}
\hline \multirow[b]{2}{*}{ Variable } & \multicolumn{2}{|c|}{$\begin{array}{l}\text { Doctoral / Research } \\
\qquad(\mathrm{N}=202)\end{array}$} & \multicolumn{2}{|c|}{$\begin{array}{l}\text { Master's } \\
(\mathrm{N}=245)\end{array}$} & \multicolumn{2}{|c|}{$\begin{array}{l}\text { Bachelor's } \\
(\mathrm{N}=168)\end{array}$} \\
\hline & Mean & SD & Mean & SD & Mean & SD \\
\hline Enrollment & 56 & 66 & 19 & 31 & 16 & 17 \\
\hline Tuition and fees & 19,926 & 8,285 & 15,491 & 6,086 & 22,800 & 9,011 \\
\hline Last year enrollment & 20,919 & 16,657 & 8,352 & 14,259 & 2,050 & 1,782 \\
\hline Total faculty number & 2,734 & 2,526 & 549 & 977 & 166 & 110 \\
\hline Faculty/student ratio & 7.41 & 4.35 & 4.76 & 1.46 & 6.57 & 2.27 \\
\hline Instruction share & .62 & .09 & .49 & .08 & .43 & .08 \\
\hline Service share & .09 & .04 & .13 & .04 & .15 & .05 \\
\hline Cost per degree & 86,269 & 56,603 & 60,842 & 23,572 & 109,314 & 49,247 \\
\hline Average faculty salary & 48,374 & 52,648 & 46,415 & 21,212 & 54,427 & 29,713 \\
\hline Cost per student & 34,438 & 31,397 & 14,464 & 5,798 & 27,558 & 14,342 \\
\hline Completion rate & 26.74 & 5.51 & 25.49 & 7.33 & 22.63 & 4.77 \\
\hline
\end{tabular}

Table 3 shows on average, there are more international undergraduate students enrolling in public institutions $(M=33)$ than in private institutions $(M=28)$. Also, in general, private institutions $(\mathrm{M}=\$ 23,828)$ charge $78 \%$ higher tuition and fees than public institutions $(M=\$ 13,354)$.Looking at the two institutional size variables, public institutions have much larger student enrollment $(M=17,727)$ than private institutions 
$(M=4,764)$ but international undergraduate students only represent a smaller percentage $(0.2 \%)$ of total student enrollment in public institutions compared with that in private institutions $(0.6 \%)$. Also, total faculty member $(\mathrm{M}=1,835)$ in public institutions is much bigger than that $(\mathrm{M}=587)$ in private institutions. Public institutions have higher instruction share, but lower student service share of total education related expenditures than private institutions do. On the contrary, private institutions have larger expenditure per degree and per student. Private institutions have higher average faculty salary, and higher faculty/student ratio than public institutions. For the measure of output of an institution, the completion rate in private institutions is higher than that in public institutions on average.

Table 3: Descriptive Statistics of Variables by Control (Full Sample)

\begin{tabular}{llclc}
\hline \multirow{1}{*}{ Variable } & \multicolumn{3}{c}{$\begin{array}{c}\text { Public Institutions } \\
\text { (N=286) }\end{array}$} & $\begin{array}{c}\text { Private Institutions } \\
(\mathrm{N}=329)\end{array}$ \\
\cline { 2 - 5 } & Mean & SD & Mean & SD \\
\hline Enrollment & 33 & 50 & 28 & 45 \\
Tuition and fees & 13,354 & 4,564 & 23,828 & 7,677 \\
Last year enrollment & 177,27 & 19,211 & 4,764 & 5,563 \\
Total faculty number & 1,835 & 2,419 & 587 & 1,071 \\
Faculty/student ratio & 5.41 & 1.92 & 6.76 & 3.80 \\
Instruction share & .58 & .08 & .47 & .10 \\
Service share & .10 & .04 & .14 & .05 \\
Cost per degree & 64,161 & 28,354 & 98,196 & 55,802 \\
Average faculty salary & 45,263 & 45,203 & 52,467 & 27,428 \\
\hline
\end{tabular}




\begin{tabular}{lllll}
\hline Cost per student & 18,744 & 11,462 & 29,767 & 26,737 \\
Completion rate & 22.80 & 4.16 & 27.20 & 7.17 \\
\hline
\end{tabular}

\section{Fixed Effects Regression Analysis}

To more fully examine the relationship between out-of-state tuition and fees charged by an institution and its international undergraduate student enrollment, fixed effects regression was conducted based on the model presented in Chapter 3. The regression analysis includes institution-specific fixed effects $\left(a_{i}\right)$ and year effects $\left(a_{t}\right)$. By including institution fixed effects, this analysis uses within-institution variation over time in out-of-state tuition and fees to estimate enrollment effects, net of common year effects. To account for the possibility of serial correlation in the error term, standard errors were clustered at the institution level. Also, as mentioned in Chapter 3, this study uses a double $\log$ method for the convenience of interpretation, specifically to directly get the tuition elasticity of the student demand (that is, the estimated coefficient) from the analysis. Generally speaking, the agreement in prior studies (Heller, 1997; Leslie \& Brinkman, 1987; Zhang, 2005) states that if the estimated coefficients are negative with a magnitude larger than one, the demand is said to be elastic. Otherwise, the demand is inelastic to price changes.

There are all together five tables included in this part. Three tables present the results of the fixed effects analysis including the enrollment effects of tuition increases for all the institutions in the sample, the enrollment effects of tuition and fees increases by Carnegie Classification 2005 (Doctoral/Research, Master's, and Bachelor's) and by control (public and private). Then two summary tables (Table 6 and Table 8) show the 
comparison of student's tuition elasticity and the predicted actual changes of student enrollment numbers with every $\$ 1000$ of tuition and fees increase and the SPRC in different types of institutions.

Table 4: Enrollment Effects of Tuition Increases: All Institutions (Full Sample)

\begin{tabular}{ll}
\hline \multicolumn{1}{c}{ Variable } & \multicolumn{1}{c}{ Log Enrollment } \\
\hline Log Tuition and fees & $-0.0726(0.0444)$ \\
Log Last year enrollment & $0.3132(0.0731)^{* * *}$ \\
Log Total faculty number & $-0.0235(0.0555)$ \\
Log Instruction share & $-0.1393(0.0715)$ \\
Log Service share & $0.0076(0.0324)$ \\
Log Cost per degree & $-0.2269(0.0652)^{* * *}$ \\
Log Faculty/student ratio & $0.1584(0.0416)^{* * *}$ \\
Log Average faculty salary & $0.0543(0.0504)$ \\
Log Cost per student & $0.2086(0.0565)^{* * *}$ \\
Log Completion rate & $-0.3990(0.0734)^{* * *}$ \\
Number of institutions & 615 \\
Total $\mathrm{R}^{2}$ & .7478 \\
\hline
\end{tabular}

Note: Values in parentheses are robust standard errors. All models also include institution and year effects. $* *$ Significant at $5 \%$.*** Significant at $1 \%$.

Table 4 presents the overall enrollment effects of tuition increase for all the institutions in the full sample without breaking them into institution types. It is estimated that the average out-of-state tuition elasticity of international undergraduate students is - 
0.0726. Referring back to Table 4, it is interpreted as evaluated at the means (approximately $\$ 18,916$ tuition and fees and student enrollment of 31), a \$1000 increase in tuition and fees would lead to a decline in international undergraduate student enrollment of approximately 0.1 students, or a little more than $0.4 \%$. If we transform this estimate into a SPRC then the SPRC for international undergraduate students from this study is -0.4 . This estimate can be better understood by comparing with some similar research based on U.S. domestic students.

For example, a recent study from Hemelt and Marcotte (2011) estimated that the average tuition and fees elasticity of full-time first-time undergraduate enrolled into public colleges and universities between 1991 and 2006 was -0.1147 with a calculated SPRC of -0.27 . The conclusion for their study is student enrollment is inelastic to tuition and fees change during the data period and thus, tuition can be used as a lever to offset revenue losses from declining appropriations for public four-year institutions. Then, back to the SPRC estimate of -0.4 calculated by this study, we can say, in general, international undergraduate student enrollment is inelastic to tuition increase in U.S. fouryear intuitions within the data period (1991-2010). In this case, the student demand is considered inelastic, i.e., the magnitude of the estimated coefficients is less than unitary. This result indicates an increase in out-of-state tuition and fees would increase tuition revenue for the U.S. four-year institutions.

However, does this general result based on all institutions in Table 4 hold true when various institution types are put into consideration? As indicated in the descriptive statistics, the institutions with different attributes in the sample data set display dramatically different levels of required tuition and fees and numbers of international 
undergraduate student enrollment. It urges this study to take a further step to examine whether the general relationship between tuition and fees and international undergraduate student enrollment estimated in Table 4 is different for different types of institutions. This is also the second research question of this specific study that needs to be answered. Table 5 presents the results of the model identical to that in Table 4 but estimated separately for the enrollment effects of tuition increases by Doctoral/Research, Master's and Bachelor's institutions (by Carnegie Classification 2005).

\section{Table 5: Enrollment Effects of Tuition Increases: By Carnegie Classification 2005} (Full Sample)

\begin{tabular}{lccc}
\hline & & Log Enrollment & \\
\cline { 2 - 4 } \multicolumn{1}{c}{ Variable } & Doctoral/Research & Master's & Bachelor's \\
\hline $\begin{array}{l}\text { Log Tuition and } \\
\text { fees }\end{array}$ & $-0.2200(0.0842)^{* * *}$ & $-0.2401(0.0909)^{* * *}$ & $-0.0796(0.0624)$ \\
$\begin{array}{l}\text { Log Last year } \\
\text { enrollment }\end{array}$ & $0.1567(0.1277)^{* *}$ & $0.5050(0.1421)^{* * *}$ & $-0.6668(0.1480)$ \\
$\begin{array}{l}\text { Log Total faculty } \\
\text { number }\end{array}$ & $-0.1306(0.0711)$ & $-0.7273(0.1225)$ & $0.2666(0.1181)^{* *}$ \\
$\begin{array}{l}\text { Log Instruction } \\
\text { share }\end{array}$ & $0.0029(0.1005)$ & $-0.0997(0.1683)$ & $-0.4566(0.1317)^{* * *}$ \\
$\begin{array}{l}\text { Log Service share } \\
\text { Log Cost per degree }\end{array}$ & $-0.0744(0.0435)$ & $-0.0745(0.0648)$ & $-0.0097(0.0603)$ \\
$\begin{array}{l}\text { Log Faculty/student } \\
\text { ratio }\end{array}$ & $0.1785(0.0575)^{* * *}$ & $0.1291(0.0903)$ & $0.2947(0.1076)^{* * *}$ \\
$\begin{array}{l}\text { Log Average } \\
\text { faculty salary }\end{array}$ & $0.0167(0.0596)$ & $-0.0179(0.1194)$ & $0.3270(0.1085)^{* *}$ \\
$\begin{array}{l}\text { Log Cost per } \\
\text { student }\end{array}$ & $0.3945(0.0949)^{* * *}$ & $0.2710(0.1135)^{* * *}$ & $-0.2764(0.1092)^{* *}$ \\
\hline
\end{tabular}




\begin{tabular}{llll}
\hline $\begin{array}{l}\text { Log Completion } \\
\text { rate }\end{array}$ & $-0.6865(0.1317) * * *$ & $-0.2672(0.1292) * *$ & $-0.2366(0.1407)$ \\
$\begin{array}{l}\text { Number of } \\
\text { institutions }\end{array}$ & 202 & 245 & 168 \\
Total $\mathrm{R}^{2}$ & .5992 & .6706 \\
& .7696 & & \\
\hline $\begin{array}{l}\text { Note: Values in parentheses are robust standard errors. All models also include institution } \\
\text { and year effects. }\end{array} *$ Significant at 5\%. *** Significant at $1 \%$.
\end{tabular}

Table 5 shows there is a significant difference of student enrollment responses to tuition and fees across these three institution types. All the negative signs before the three elasticity values indicate, in general, international undergraduate student enrollment decreased when tuition and fees increased during the 20 -year sample period. The tuition elasticity of international undergraduate student enrollment are roughly the same in Doctoral/Research and Master's institutions (-0.2200 vs -0.2401). The tuition elasticity of international undergraduate student enrollment is smallest at Bachelor's institutions (0.0796). The magnitudes of these estimates indicate international undergraduate students are generally less elastic to the tuition and fees increase in Bachelor's institutions than that in Doctoral/Research institutions. As mentioned earlier, compared with Doctoral/Research and Master's institutions, Bachelor's institutions charge the highest average tuition and fees to international undergraduate students but it is not as vulnerable to the decline of student enrollment with the same level of tuition increase as in the other two types of institutions.

Notice that the variable of tuition and fees is a statistically significant factor affecting the international undergraduate student enrollment in Doctoral/Research and Master's institutions. A couple of variables for measuring all the three aspects of the 
institutional quality are statistically significant including inputs (last year total enrollment), process (cost per degree, faculty/student ratio, and cost per student), and outputs (completion rate). On contrast, the tuition and fees factor is not statistically significant in Bachelor's institutions. Also, the tuition elasticity of international undergraduate student enrollment is the smallest (-0.0796) among all the three institution types. This indicates tuition and fees is not an affecting factor for international undergraduate student enrollment in Bachelor's institutions.

Some control variables measuring institutional quality are statistically significant in the model of Bachelor's institutions including the total number of faculty members, the instruction share of total education related expenditure, the faculty/student ratio, the average faculty salary and cost per student. This for Bachelor's institutions, tuition and fees changes may not be an effective strategy for increasing revenue or increasing international undergraduate student participation in these institutions. Rather, improving institutional quality could be worthy of trying if Bachelor's institutions want to improve their international undergraduate student enrollment.

Table 6 displays a comparison of tuition elasticity of international undergraduate enrollment in all institutions in general and the three Carnegie four-year institution types. In the column of elasticity, all the negative signs of the elasticity values indicate international undergraduate student enrollment declines when tuition and fees increases. However, the absolute value of the magnitude indicates the degree of the elasticity varies significantly across all the three Carnegie types of institutions. More specifically, tuition and fees increase mostly affect international undergraduate student enrollment in 
Master's institutions, moderately affect Doctoral/Research institutions and exert little to none effect to Bachelor's institutions.

Table 6: Price Elasticity by Carnegie 2005 Institution Type (Full Sample)

\begin{tabular}{lccccc}
\hline Institution Type & Elasticity & $\begin{array}{l}\text { Enrollment } \\
\text { (Mean) }\end{array}$ & $\begin{array}{l}\text { Tuition } \\
\text { (Mean) }\end{array}$ & $\begin{array}{l}\text { Enrollment } \\
\text { Number } \\
\text { Change / } \\
\$ 1000\end{array}$ & $\begin{array}{c}\text { SPRC } \\
\text { (Enrollment \% } \\
\text { change/ } \$ 100)\end{array}$ \\
\hline All Institutions & -0.0726 & 31 & 18,916 & 0.1 & -0.4 \\
Doctoral/Research & -0.2200 & 56 & 19,926 & 0.6 & -1.1 \\
Master's & -0.2401 & 19 & 15,491 & 0.3 & -1.5 \\
Bachelor's & -0.0796 & 16 & 22,800 & 0.1 & -0.3 \\
\hline
\end{tabular}

The third column presents the international undergraduate student number change per $\$ 1000$ tuition and fees increase. These numbers indicate every $\$ 1000$ tuition and fees increase could lead to a decline of 0.1-0.6 students in different institutions. These numbers look really small compared with the enrollment decline of domestic students of 100-300 per every $\$ 1000$ tuition and fees on average because international undergraduate students only consists of less than $2 \%$ of the undergraduate populations in most institutions and the mean student number is as small as 31 on average. The last column is a transformed value from elasticity into a standard comparable value of student priceresponse coefficient (SPRC)used widely in student demand studies literature, especially Leslie and Brinkman (1987), to indicate the percentage change of student enrollment with every $\$ 100$ of tuition increase. 
Table 7: Enrollment Effects of Tuition Increases: By Control (Full Sample)

\begin{tabular}{lll}
\hline \multirow{2}{*}{ Variable } & \multicolumn{2}{c}{ Log Enrollment } \\
\cline { 2 - 3 } & Public Institutions & Private Institutions \\
\hline Log Tuition and fees & $-0.3464(0.0664)^{* * * *}$ & $0.0943(0.0605)$ \\
Log Last year enrollment & $0.5772(0.1326)^{* * *}$ & $0.0595(0.0954)$ \\
Log Total faculty number & $-0.0027(0.0991)$ & $0.1847(0.0774)^{* *}$ \\
Log Instruction share & $0.4111(0.1838)^{* *}$ & $-0.2731(0.0793)^{* * *}$ \\
Log Service share & $0.0691(0.0579)$ & $0.0638(0.0402)$ \\
Log Cost per degree & $0.0112(0.1266)$ & $0.0068(0.0879)$ \\
Log Faculty/student ratio & $0.2601(0.0662)^{* * *}$ & $0.1796(0.0566)^{* * *}$ \\
Log Average faculty salary & $0.1623(0.0894)$ & $0.1890(0.0721)^{* * *}$ \\
Log Cost per student & $0.0987(0.1093)$ & $-0.1042(0.0831)$ \\
Log Completion rate & $-0.4824(0.1376)^{* * *}$ & $-0.1695(0.0932)$ \\
Number of institutions & 286 & 329 \\
Total $\mathrm{R}^{2}$ & .7418 & .7545 \\
\hline
\end{tabular}

Note: Values in parentheses are robust standard errors. All models also include institution and year effects. $* *$ Significant at $5 \%$. $* * *$ Significant at $1 \%$.

Table 7 displays the international undergraduate student enrollment responses to tuition and fees in both public and private institutions. In public institutions, the tuition elasticity of international undergraduate student enrollment is -0.3464 . In contrast, for private institutions, the tuition elasticity of international undergraduate student enrollment is 0.0943 with a positive sign. These estimates indicate there are remarkable differences between private and public institutions. Also, the different signs before the elasticity 
indicate tuition increase can lead to international undergraduate student enrollment decline in public institutions but not in private institutions.

Notice the variable of tuition and fees is statistically significant in public institutions but not in private institutions. This indicates tuition and fees could be a factor affecting international undergraduate student enrollment in public institutions. Also, a couple of control variables are statistically significant in the model including the last year total enrollment, the instruction share of the total education related expenditures, the faculty/student ratio, and the completion rate of the institutions. These variables measure all the quality of inputs, process and outputs of public institutions. While for private institutions, tuition and fees may not be a key factor determining their level of international undergraduate student enrollment, rather some control variables measuring the quality of process in private institutions stand out indicating the quality of faculty member and the quality of instruction are more importantly considered by the students.

Table 8: Price Elasticity by Control (Full Sample)

\begin{tabular}{lccccc}
\hline Institution Type & Elasticity & $\begin{array}{l}\text { Enrollment } \\
\text { (Mean) }\end{array}$ & $\begin{array}{l}\text { Tuition } \\
(\text { Mean) }\end{array}$ & $\begin{array}{l}\text { Enrollment } \\
\text { Number } \\
\text { Change / } \\
\$ 1000\end{array}$ & $\begin{array}{c}\text { SPRC } \\
\text { (Enrollment } \% \\
\text { change/ } \$ 100)\end{array}$ \\
\hline All Institutions & -0.0726 & 31 & 18,916 & 0.1 & -0.4 \\
Public & -0.3464 & 33 & 13,354 & 1 & -2.6 \\
Private & 0.0943 & 28 & 23,828 & 0.1 & 0.4 \\
\hline
\end{tabular}

Table 8 is another summary table similar to Table 6 but the institutions are grouped by control instead of the three levels of Carnegie classification. In the column of 
elasticity, public institutions have negative signs and smaller magnitude (less than 1) which indicate international undergraduate student enrollment will decrease when tuition and fees increases. Also, the degree of tuition elasticity is different between public research and non-research institutions. More specifically, based on the third column about the international undergraduate student number change per $\$ 1000$ tuition and fees increase, the SPRC are calculated and presented in the last column which shows the student enrollment is much elastic to tuition and fees increase in public research institutions than that in private institutions.

\section{Shorter Sample Analysis (2005-2010)}

\section{Descriptive Statistics}

Table 9 presents the descriptive statistics of all the major variables used in this shorter sample analysis. Based on the same 615 four-year institutions which report their international undergraduate student enrollment during 2005-2010, this study collects a total number of 3,690 observations. During this shorter period, the mean of international undergraduate student enrollment in these institutions becomes $40(\mathrm{SD}=64)$ compared with the mean of $31(\mathrm{SD}=48)$ in the full sample. The mean of out-of-state tuition and fees is $\$ 21,638$ ( $\mathrm{SD}=8541)$ compared with the mean of $\$ 18,917(\mathrm{SD}=8270)$ in the full sample. Additionally, three new variables help measuring the quality of inputs and the quality of outcomes are added to the analysis. They are admissions rate, SAT median and (secondyear) retention rate.

\section{Table 9: Descriptive Statistics of Variables (Shorter Sample)}

$\begin{array}{llllll}\text { Variable } & \text { N } & \text { Mean } & \text { SD } & \text { Minimum } & \text { Maximum }\end{array}$




\begin{tabular}{llllll}
\hline Enrollment & 3,462 & 40 & 65 & 1 & 798 \\
Tuition and fees & 3,462 & 21,638 & 8541 & 2575 & 47,279 \\
Admissions rate & 3,462 & .64 & .19 & .07 & .99 \\
SAT median & 3,462 & 1,111 & 138 & 10 & 1,525 \\
Last year enrollment & 3,462 & 12,025 & 16,750 & 331 & 244,273 \\
Total faculty number & 3,462 & 1,450 & 2,238 & 28 & 25,644 \\
Faculty/student ratio & 3,462 & 6.42 & 3.94 & 0.16 & 50.52 \\
Cost per student & 3,462 & 24,800 & 23,711 & 53 & 273,462 \\
Instruction share & 3,462 & .51 & .11 & .20 & .86 \\
Service share & 3,462 & .13 & .06 & .01 & .34 \\
Cost per degree & 3,462 & 83,196 & 52,987 & 182 & 561,177 \\
Average faculty salary & 3,462 & 53,862 & 51,193 & 99 & $2,610,347$ \\
Retention rate & 3,462 & .79 & .10 & .19 & 1.00 \\
Completion rate & 3,462 & 25.87 & 6.05 & 6.75 & 74.39 \\
\hline
\end{tabular}

Note: All monetary values are expressed in 2010 values. The analytical sample includes a total of 615 institutions.

Similarly to what has been done to the full sample, two additional descriptive tables (Table 10 and Table 11) are added to give a fuller picture of the shorter sample. Table 10 presents the means comparison of variables by Carnegie (four-year) institution types (Research/Doctoral, Master's, and Bachelor's). It shows there are remarkable differences of both international undergraduate student enrollment and out-of-state tuition and fees in various institution types. Generally speaking, Doctoral/Research institutions still host largest number of international undergraduate students $(\mathrm{M}=80)$ compared with Master's institutions $(\mathrm{M}=22)$ and Bachelor's institutions $(\mathrm{M}=18)$. For the required out-of- 
state tuition and fees charged to international students, among the three Carnegie categories, Bachelor's institutions charge the highest tuition and fees to international undergraduate students $(\mathrm{M}=\$ 25,571)$, followed by Doctoral/Research institutions (Mean=\$23,131). Still, Master's institutions charge the lowest tuition and fees (Mean $=\$ 17,976)$ to international undergraduate students compared with other two institution categories.

Table 10: Means Comparison of Variables by Carnegie Institution Type (Shorter Sample)

\begin{tabular}{lllllll}
\hline \multirow{1}{*}{\multicolumn{1}{c}{ Variable }} & \multicolumn{2}{c}{$\begin{array}{c}\text { Doctoral / Research } \\
(\mathrm{N}=202)\end{array}$} & \multicolumn{2}{c}{$\begin{array}{c}\text { Master's } \\
(\mathrm{N}=245)\end{array}$} & \multicolumn{2}{c}{$\begin{array}{c}\text { Bachelor's } \\
(\mathrm{N}=168)\end{array}$} \\
\cline { 2 - 7 } & Mean & $\mathrm{SD}$ & Mean & SD & Mean & SD \\
Enrollment & 80 & 96 & 22 & 26 & 18 & 16 \\
Tuition and fees & 23,131 & 8343 & 17,826 & 6,558 & 25,571 & 9,094 \\
Admissions rate & .61 & .21 & .68 & .15 & .62 & .21 \\
SAT median & 1,171 & 133 & 1,035 & 94 & 1,152 & 146 \\
Last year enrollment & 22,870 & 18,323 & 9,371 & 15,692 & 2,179 & 2,013 \\
Total faculty number & 3,344 & 2,792 & 680 & 1,153 & 202 & 125 \\
Faculty/student ratio & 7.90 & 5.80 & 4.65 & 1.34 & 7.22 & 2.22 \\
Cost per student & 36,107 & 34,525 & 13,997 & 5,635 & 26,871 & 14,886 \\
Instruction share & .61 & .09 & .49 & .07 & .43 & .07 \\
Service share & .09 & .04 & .14 & .05 & .17 & .05 \\
Cost per degree & 88,227 & 63,413 & 58,777 & 22,415 & 114,219 & 53,695 \\
Average faculty salary & 52,450 & 77,867 & 51,126 & 23,119 & 59,872 & 36,876 \\
\hline
\end{tabular}




\begin{tabular}{lllllll}
\hline Retention rate & .84 & .09 & .75 & .08 & .80 & .12 \\
Completion rate & 27.47 & 5.44 & 26.54 & 6.80 & 22.79 & 4.20 \\
\hline
\end{tabular}

Note: All monetary values are expressed in 2010 values. The analytical sample includes a total of 615 institutions.

Table 11 presents the means comparison of variables by control of institutions. It generally shows there are remarkable differences of international undergraduate student enrollment between public and private institutions during the sample data period (20052010). On average, there are more international undergraduate students enrolled in public institutions $(M=47)$ than in private institutions $(M=34)$ in the shorter sample period which is consistent with the result from the full sample as well. Also, in general, private institutions $(M=\$ 26,986)$ charge $73 \%$ higher tuition and fees than public institutions $(\mathrm{M}=\$ 15,571)$.However, during the sample period, tuition and fees increased 1.5 times faster in public institutions than that in private institutions.

\section{Table 11: Descriptive Statistics of Variables by Control (Shorter Sample)}

\begin{tabular}{llclc}
\hline \multirow{1}{*}{ Variable } & \multicolumn{3}{c}{$\begin{array}{c}\text { Public Institutions } \\
(\mathrm{N}=286)\end{array}$} & $\begin{array}{c}\text { Private Institutions } \\
(\mathrm{N}=329)\end{array}$ \\
\cline { 2 - 5 } & Mean & $\mathrm{SD}$ & Mean & $\mathrm{SD}$ \\
\hline Enrollment & 47 & 76 & 34 & 52 \\
Tuition and fees & 15,744 & 4,895 & 27,002 & 7,560 \\
Admissions rate & .68 & .16 & .61 & .21 \\
SAT median & 1,063 & 106 & 1,155 & 148 \\
Last year enrollment & 19,405 & 21,067 & 5,307 & 6,112 \\
\hline
\end{tabular}




\begin{tabular}{lllll}
\hline Total faculty number & 2,188 & 2,728 & 779 & 1,359 \\
Faculty/student ratio & 5.36 & 2.21 & 7.38 & 4.82 \\
Cost per student & 18,690 & 12,030 & 30,363 & 29,624 \\
Instruction share & .57 & .09 & .46 & .10 \\
Service share & .10 & .04 & .15 & .06 \\
Cost per degree & 61,454 & 29,887 & 102,986 & 61,068 \\
Average faculty salary & 51,042 & 68,813 & 56,428 & 26,148 \\
Retention rate & .77 & .09 & .82 & .11 \\
Completion rate & 23.80 & 3.93 & 27.76 & 6.96 \\
\hline
\end{tabular}

Note: All monetary values are expressed in 2010 values. The analytical sample includes a total of 615 institutions.

\section{Fixed Effects Regression Analysis}

To more fully examine the relationship between out-of-state tuition and fees charged by an institution and its international undergraduate student enrollment during the period of 2005-2010, and test the results this study found from the full sample, a separate fixed effects regression is conducted based on the same model used in the full sample (1991-2010) only by adding the three newly available variables: admissions rate, SAT median, and the (second-year) retention rate of the institutions. There are all together five tables included in this part. The same as that in the full sample, this part presents three tables on the results of the fixed effects analysis including the enrollment effects of tuition increases for the shorter sample, more specifically, the enrollment effects of tuition and fees increases by Carnegie Classification 2005 (Doctoral/Research, Master's, and Bachelor's) and by control (public and private) of institutions. Then, 
additional two summary tables (Table 14 and Table 16) display the overall tuition elasticity of student enrollment and the comparison of elasticity among different institution types.

Table 12: Enrollment Effects of Tuition Increases (Shorter Sample)

\begin{tabular}{ll}
\hline \multicolumn{1}{c}{ Variable } & Log Enrollment \\
\hline Log Tuition and fees & $-0.2312(0.1344)$ \\
Log Admissions rate & $-0.0679(0.0637)$ \\
Log SAT median & $0.0244(0.1108)$ \\
Log Last year enrollment & $0.1598(0.2385)$ \\
Log Total faculty number & $-0.2894(0.1797)$ \\
Log Instruction share & $0.1807(0.2355)$ \\
Log Service share & $0.1130(0.0914)$ \\
Log Cost per degree & $-0.0317(0.1797)$ \\
Log Cost per student & $0.1390(0.2062)$ \\
Log Faculty/student ratio & $0.2413(0.0839)^{* * *}$ \\
Log Average faculty salary & $-0.1060(0.1738)$ \\
Log Retention & $0.0864(0.1890)$ \\
Log Completion rate & $-0.2743(0.1870)$ \\
Number of institutions & 615 \\
Total ${ }^{2}$ & .8665 \\
\hline Note: Values in parentheses are robust standard errors. All models also include institution \\
and year effects. ** Significant at $5 \%$. &
\end{tabular}


Table 12 presents the overall enrollment effects of tuition increase for the shorter sample without breaking them into institution types. It is estimated that the average outof-state tuition elasticity of international undergraduate students is -0.2312 . Compared with the tuition elasticity estimated in the full sample (-0.0726), international undergraduate student enrollment had been more sensitive to tuition changes in the more recent six-year sample. Then, similar to what has been done to the full sample this study further checked if this general result based on all institutions in Table 12 hold true when various institution types are put into consideration. Table 13 presents the results of the model identical to that in Table 12 but estimated separately for the enrollment effects of tuition increases by Doctoral/Research, Master's and Bachelor's institutions (by Carnegie Classification 2005).

Table 13 shows there is still significant difference of student enrollment responses to tuition and fees across these three institution types. The tuition elasticity of international undergraduate student enrollment is largest at Bachelor's institutions (1.7140). This estimate indicates international undergraduate students are sensitive or elastic to the tuition and fees increase in Bachelor's institutions during the shorter sample period. As noticed, compared with Doctoral/Research and Master's institutions, Bachelor's institutions have been charging the highest average tuition and fees to international undergraduate students both during the 20-year data set and this recent 6year data set. Although international undergraduate student enrollment in Bachelor's institutions was not much affected by their tuition increase in general, it is noteworthy that during these most recent time period of 2005-2010, they have become more 
vulnerable to the decline of student enrollment with the same level of tuition increase as in the other two types of institutions.

Table 13: Enrollment Effects of Tuition Increases: By Carnegie Classification (Shorter Sample)

\begin{tabular}{|c|c|c|c|}
\hline \multirow[b]{2}{*}{ Variable } & \multicolumn{3}{|c|}{ Log Enrollment } \\
\hline & Doctoral/Research & Master's & Bachelor's \\
\hline Log Tuition and fees & $-0.5159(0.1746) * * *$ & $-0.0559(0.2193)$ & $-1.7140(0.5277) * * *$ \\
\hline Log Admissions rate & $0.0435(0.1277)$ & $-0.0970(0.0981)$ & $0.0422(0.1185)$ \\
\hline Log SAT median & $0.0732(0.0981)$ & $-0.8864(0.7272)$ & $0.7203(0.7601)$ \\
\hline $\begin{array}{l}\text { Log Last year } \\
\text { enrollment }\end{array}$ & $0.5897(0.3768)$ & $0.7195(0.4375)$ & $-0.6610(0.4408)$ \\
\hline $\begin{array}{l}\text { Log Total faculty } \\
\text { number }\end{array}$ & $-0.7511(0.3355)^{* *}$ & $-0.3354(0.4516)$ & $0.2962(0.3450)$ \\
\hline Log Instruction share & $0.9299(0.3986) * *$ & $0.1085(0.5871)$ & $-0.1720(0.3891)$ \\
\hline Log Service share & $0.2350(0.1189)$ & $0.1457(0.2454)$ & $0.0268(0.1902)$ \\
\hline Log Cost per degree & $0.0358(0.3321)$ & $-0.1877(0.2853)$ & $-0.1311(0.3443)$ \\
\hline Log Cost per student & $0.4470(0.3522)$ & 0.7004 (0.4007) & $-0.5807(0.4039)$ \\
\hline $\begin{array}{l}\text { Log Faculty/student } \\
\text { ratio }\end{array}$ & $0.3087(0.1230) * *$ & $0.0620(0.1520)$ & $0.5928(0.2991)^{* *}$ \\
\hline $\begin{array}{l}\text { Log Average faculty } \\
\text { salary }\end{array}$ & $-0.4559(0.3133)$ & $-0.2756(0.3111)$ & $0.7063(0.3189)^{* *}$ \\
\hline Log Retention rate & $-0.1345(0.3649)$ & $-0.2040(0.3370)$ & $0.4108(0.3105)$ \\
\hline Log Completion & $-0.5031(0.3638)$ & $-0.1098(0.3377)$ & $-0.5403(0.3629)$ \\
\hline Number of Institutions & 202 & 245 & 167 \\
\hline Total $\mathrm{R}^{2}$ & .8693 & .7762 & .8203 \\
\hline
\end{tabular}


Note: Values in parentheses are robust standard errors. All models also include institution and year effects. $\quad * *$ Significant at 5\%. *** Significant at $1 \%$.

Table 13 also shows the tuition elasticity of international undergraduate student enrollment at Doctoral/Research institutions is -0.5159 which is also a big increase from the tuition elasticity of -0.2200 estimated in the full sample. In general, this estimate shows international undergraduate student enrollment in Doctoral/Research institutions has also become more sensitive to tuition increases during the 6-year period of shorter sample. While in Master's institutions, the tuition elasticity of international undergraduate student enrollment is the smallest (-0.0559) among all the three institution types, none of the control variables are statistically significant in the model. This indicates international undergraduate students are almost not sensitive to the tuition change in these institutions and neither tuition and fees nor the widely used quality indicators are affecting factors for international undergraduate student enrollment in Master's institutions. Therefore, tuition and fees changes may not be an effective strategy for increasing revenue or increasing international undergraduate student participation in Master's institutions.

Table 14 shows a comparison of tuition elasticity of international undergraduate enrollment in all institutions and that in the three Carnegie 2005 types of institutions. Again, in the column of elasticity, all the negative signs of the elasticity values indicate international undergraduate student enrollment will decline when out-of-state tuition and fees increase. However, the absolute value of the magnitude indicates the degree of the elasticity varies significantly across all the three Carnegie types of institutions. During this shorter period, tuition and fees increase will mostly affect international 
undergraduate student enrollment in Bachelor's institutions, moderately affect Doctoral/Research institutions and exert little to none effect to Master's institutions. The third column presents the international undergraduate student number change per $\$ 1000$ tuition and fees increase. The last column is the SPRC of international undergraduate student enrollment calculated based on this shorter sample.

Table 14: Price Elasticity by Carnegie 2005 Institution Type (Shorter Sample)

\begin{tabular}{lccccc}
\hline Institution Type & Elasticity & $\begin{array}{l}\text { Enrollment } \\
\text { (Mean) }\end{array}$ & $\begin{array}{l}\text { Tuition } \\
\text { (Mean) }\end{array}$ & $\begin{array}{l}\text { Enrollment } \\
\text { Number } \\
\text { Change / } \\
\$ 1000\end{array}$ & $\begin{array}{c}\text { SPRC } \\
\text { (Enrollment } \% \\
\text { change/ } \$ 100)\end{array}$ \\
\hline All Institutions & -0.2312 & 40 & 21,638 & 0.5 & -0.12 \\
Doctoral/Research & -0.5159 & 80 & 23,132 & 2 & -0.23 \\
Master's & -0.0559 & 22 & 17,826 & 0.1 & -0.03 \\
Bachelor's & -1.7140 & 17 & 25,571 & 1 & -0.67 \\
\hline
\end{tabular}

Table 15 displays the international undergraduate student enrollment responses to tuition and fees in both public and private institutions. In public institutions, the tuition elasticity of international undergraduate student enrollment is -0.2930 . In contrast, for private institutions, tuition and fees factor is not statistically significant in the model which means the increase of out-of-state tuition and fees does not exert any influence to international undergraduate student enrollment in private institutions in the data period. This result indicates international undergraduate student enrollment is not sensitive to tuition and fees changes in private institutions. 
Table 15: Enrollment Effects of Tuition Increases: By Control (Shorter Sample)

\begin{tabular}{lll}
\hline \multicolumn{1}{c}{ Variable } & Public Institution & Private Institution \\
& Log IFFTU Enrollment & Log IFFTU Enrollment \\
\hline Log Tuition and fees & $-0.2930(0.1442)^{* * *}$ & $0.6956(0.4971)$ \\
Log Admissions rate & $0.0769(0.0976)$ & $-0.1701(0.0846)^{* *}$ \\
Log SAT median & $0.0109(0.1148)$ & $0.3591(0.5918)$ \\
Log Last year enrollment & $0.1935(0.4376)$ & $0.2746(0.3054)$ \\
Log Total faculty number & $-0.3911(0.3468)$ & $-0.2913(0.2341)$ \\
Log Instruction share & $-0.2302(0.4587)$ & $0.4408(0.2833)$ \\
Log Service share & $0.1979(0.1572)$ & $0.0951(0.1140)$ \\
Log Cost per degree & $0.3815(0.3012)$ & $-0.3497(0.2379)$ \\
Log Cost per student & $0.0862(0.3505)$ & $0.3970(0.2802)$ \\
Log Faculty/student ratio & $0.1645(0.1189)$ & $0.4211(0.1732)^{* *}$ \\
Log Average faculty salary & $-0.2738(0.3378)$ & $-0.0591(0.2240)$ \\
Log Retention rate & $-0.0407(0.3028)$ & $0.2705(0.2555)$ \\
Log Completion & $0.0998(0.3016)$ & $-0.5293(0.2513)^{* *}$ \\
Number of institutions & 285 & 329 \\
Total ${ }^{2}$ & .8604 & .8694 \\
\hline No: Var & & \\
\hline
\end{tabular}

Note: Values in parentheses are robust standard errors. All models also include institution and year effects. $* *$ Significant at $5 \%$. $* * *$ Significant at $1 \%$.

Table 16 is another summary table similar to Table 14 but the institutions are grouped by control instead of the three levels of Carnegie classification. In Table 16, it displays the comparison of tuition elasticity of international undergraduate enrollment in 
public and private institutions. In the column of elasticity, public institutions have negative signs and smaller magnitude (less than 1) which indicate international undergraduate student enrollment will decrease when tuition and fees increases. Also, the degree of tuition elasticity is different between these two types of institutions. This could be explained by the third column about the international undergraduate student number change per $\$ 1000$ tuition and fees increase and the SPRC presented in the last column.

\section{Table 16: Price Elasticity by Control (Shorter Sample)}

\begin{tabular}{lccccc}
\hline Institution Type & Elasticity & $\begin{array}{l}\text { Enrollment } \\
\text { (Mean) }\end{array}$ & $\begin{array}{l}\text { Tuition } \\
\text { (Mean) }\end{array}$ & $\begin{array}{l}\text { Enrollment } \\
\text { Number } \\
\text { Change / } \\
\$ 1000\end{array}$ & $\begin{array}{c}\text { SPRC } \\
\text { (Enrollment \% } \\
\text { change/ } 100)\end{array}$ \\
\hline All Institutions & -0.2312 & 40 & 21,638 & 0.5 & -0.12 \\
Public & -0.2930 & 47 & 15,744 & 1 & -0.19 \\
Private & 0.6956 & 34 & 27,002 & 1 & 0.26 \\
\hline
\end{tabular}

\section{Summary}

To sum up, this Chapter 4 presents the findings of descriptive analysis and fixed effects regression analysis based on two samples. This research estimates that the tuition elasticity of first-time full-time international undergraduate degree/certificate-seeking student enrollment in U.S. four-year institutions is less than the unitary which indicates international undergraduate students are generally inelastic to out-of-state tuition and fees charged by the institutions. However, owing to the large variations among all the institutions, tuition elasticity has been found significantly different in different types of 
institutions. More specifically, international undergraduate students are generally inelastic to tuition changes in Doctoral/Research institutions. In recent years, students become more tuition elastic to Bachelor's institutions than before. In addition, international undergraduate student enrollment is more elastic in public institutions than in private institutions.

However, there is no prior established theory or practice about elasticity estimation based on international undergraduate student enrollment studies for this current research to compare and test whether the estimates are accurate or the interpretation of the estimates are appropriate for this unique student group in U.S. higher education. Prior studies (Agarwal\& Winkler, 1985; Solomon \& Yong, 1987) have found that international students are also price-responsive, but may not be in the same way as domestic students since tuition is not as much a factor for international students as it for domestic ones. International students tend to have different expectations of investment return than domestic students. Additionally, in practice, international undergraduate applicants may not be able to or want to thoroughly compare each variable for measuring the quality of U.S. higher education institutions and made their decision of destination institutions based on precise calculation or rational analysis. 


\section{CHAPTER 5: CONCLUSIONS AND IMPLICATIONS}

This final Chapter includes four parts. The first part is an overview of the study to restate the research purpose, design, and the general procedures conducted in the study. The second part is a summary and comparison of the research results framed within the two proposed research questions. The third part describes the implications drawn from this study for higher education theory, institutional policy, and future research based upon the limitations of this study. The final part concludes the study.

\section{Overview of the Study}

The purpose of this study is to examine how out-of-state tuition and fees affects international undergraduate student enrollment at U.S. four-year institutions. The two specific research questions this study asks are:

1) Is international undergraduate enrollment related to changes in institutional out-of-state tuition and fees?

2) Is the relationship between international undergraduate enrollment and out-ofstate tuition and fees moderated by institutional type?

This study was motivated by the fact that international undergraduate students, who typically are full-fee paying students, have become an increasingly important student group on campuses of U.S. higher education institutions for revenue generation purposes. Better knowledge of factors affecting the enrollment of this specific group of students is critical for better attracting and hosting the students and assures institutions pursue the expected economic, academic and cultural benefits that international undergraduate students offer. 
By integrating the major findings from the international student literature and U.S. domestic student demand studies, this study proposed a modified demand theory as the theoretical framework to guide the design of the research. Based on the literature, this study posits that despite the wealth of information on international student mobility around the globe, the adjustment and engagement issues of international students on U.S. campuses, and college demand studies about how institutional features affect U.S. domestic students' choice of attendance, there is very limited research on international student' demand and what factors are impacting on their enrollment in specific institutions in the U.S. However, price of attendance, student financial ability, student preferences of institutional types, and quality can be used as key factors for understanding international undergraduate student enrollment behaviors in the U.S.

Methodologically, this study adopted a quantitative research design by using a national level large-scale longitudinal data set to avoid the weaknesses of previous quantitative and qualitative studies that used small student samples and limited to a small number of institutions. The data source was the Delta Cost Project version of IPEDS which had been widely used as a reliable and effective data source for higher education research. The dependent variable of this study was the total number of international undergraduate student enrollment at a four-year institution. The key independent variable was the out-of-state tuition and fees charged to international undergraduate students by an institution.

Additionally, three vectors of variables for measuring the quality of institutional inputs, process, and outputs respectively were added as controls for the results. For a better capture of the changing relationship between international undergraduate student 
enrollment and tuition increases in the sample, the fixed effects regression was conducted twice to analyze both a full sample data range from 1991 to 2010 and a shorter sample focused on the specific period of 2005-2010 where unprecedented fast increase of institutional tuitions and student enrollment were identified and more control variables measuring institutional quality became available in the data source.

\section{Discussion of the Research Findings}

\section{Research Question One}

Research question one asks: Is international undergraduate enrollment related to changes in institutional out-of-state tuition and fees? The analytical results of this study reveal that in general, during the period of 1991-2010, international undergraduate student enrollment numbers increased significantly in despite the concurrent increase of tuition and fees charged by U.S. four-year institutions. Based on both the full sample and the shorter sample, this study estimated a negative tuition elasticity value $(-0.0726$ for the period of 1991-2010 and -0.2312 for the period of 2005-2010) for international undergraduate student enrollment in U.S. four-year institutions. This result indicates tuition increases can lead to the decline of international undergraduate student enrollment in U.S. four-year institutions. However, since the magnitudes of the elasticity are not greater than unitary, it suggests that the international undergraduate student enrollment can be considered inelastic to the institutional out-of-state tuition increases during the sample data periods.

Admittedly, the general relationship between student enrollment and tuition increase estimated in this study, to a certain degree, reinforces Agarwal and Winkler (1985), Heller (1997), and numerous other studies from the student demand literature that 
a negative price elasticity were found in educational enrollment, both domestic and international alike. However, it is not a perfect agreement to Naidoo's (2005) argument that the higher level of tuition fees charged to international students, the lower their respective demand for international education will be although his study mainly based on higher education institutions in the UK and Australia. However, the international student mobility literature provided a reasonable support to the result of this study by emphasizing the continuous and sharp increase of international mobile students around the globe during recent decades.

Basically, assuming the capacity of hosting certain number of international undergraduate students at an institution does not change much during the same period, even if the tuition increases, the real relationship between the tuition elasticity and student demand could be influenced by the entering of a large number of more financially able international students to the market at the same time. Therefore, the inelasticity of international undergraduate students to the tuition changes in U.S. four-year institutions can also partly be explained by the well-established worldwide reputation of U.S. higher education among all the international students. Li and Bray (2007) argue that the factors related to quality and reputation were the most important followed by factors relate to the funding and costs of the education and the environmental factors of the institution.

However, the result of this research cannot be interpreted as that a continuous increasing of tuition and fees will not affect international undergraduate student enrollment in U.S. higher education in a long run. Research from Naidoo (2007) reminds us that indeed, for many host educational institutions, international undergraduate students have very often been viewed as an alternative source of revenue when faced with 
reduced state-financial support and, under this market-oriented approach, many of these institutions have had a tendency to treat international undergraduate students as revenue generators. Year after year, international student fees have gone up without a true understanding of the impact on international student mobility (Kwiek, 2001). Thus, the findings from this current study should still be viewed as a caution against any further increases in international student tuition and fees.

\section{Research Question Two}

Research question two asks: Is the relationship between international undergraduate enrollments and out-of-state tuition and fees moderated by institutional type? The general relationship between international undergraduate student enrollment and institutional tuition changes based on all the four-year institutions is estimated to vary across different types of institutions. Among all the three Carnegie types of institutions, tuition and fees is a statistically significant factor affecting international undergraduate student enrollment in Doctoral/ Research institutions in both samples. During the 20 years data period, tuition increase was a factor leading to a decline of international undergraduate student enrollment in these institutions and in recent six years, international undergraduate student enrollment tend to be less inelastic than before. While for Master's and Bachelor's institutions, the relationship of tuition change and student enrollment across time are not consistent. More specifically, in Master's institutions, student enrollment was elastic to tuition and fees in the 20 years sample but turned to be inelastic in the recent 6-year sample. On the country, Bachelor's institutions experienced an opposite change of this relationship recently, that is, international undergraduate student enrollment became more elastic to tuition and fees in recent6years. 
The dominant popularity of Doctoral/Research institutions among international undergraduate students could be explained by the long established reputation and prestige of this group of institutions accumulated during the history. From the economic point of view, whether high tuition is charged or not, the higher education market is never a freely competitive market. In elite institutions, the more intense is consumer competition for entry, the less the institution finds it necessary to court the consumer in the conventional manner by dropping prices or providing more and/or better services. Providing prestige is sustained, Doctoral/Research institutions, as more elective institutions, usually have a far larger number of qualified applicants than the desired enrollment level. As a result, even with an increase in its price, those institutions are still able to attract enough qualified applicants although their number might decrease. While for those institutions which are lack of the elite or prestigious status in the whole higher education system, like the Master's and Bachelor's institutions, the laws of competition are different. In contrast, these institutions could be more influenced by the change in the number of qualified applicants due to tuition increases.

In addition, the results imply different relationships between international undergraduate student enrollment and tuition changes in institutions with public and private controls. Tuition and fees is significant factor affecting international undergraduate student enrollment in both the 20 year sample and the recent 6-year sample while in contrast, not significant in private institutions in either sample. This result shows the factor of tuition and fees has different influencing power in public and private institutions owing to the different institutional characteristics they two groups of institutions have. On average, tuition elasticity for international undergraduate student 
enrollment is becoming more elastic than before at public institutions but keeping inelastic during the 20-year data period and even becoming more inelastic during the recent 6-year sample period.

\section{Comparison of Results across Sample Periods}

Based on both the full sample and the shorter sample this study estimated negative tuition elasticity values $(-0.0726$ and -0.2312$)$ for international undergraduate student enrollment in U.S. four-year institution. This result indicates tuition increases can lead to the decline of international undergraduate student enrollment in U.S. four-year institutions. However, since the magnitudes of the elasticity are not greater than unitary, it generally suggests that the student enrollment is inelastic to the tuition increases during the sample data periods. This general relationship could be different when looking at it from different types of institution. Tuition and fees are statistically significant factor affecting international undergraduate student enrollment in Doctoral/ Research institutions in both samples. This can be explained by certain institutional attributes related to perceived quality, reputation or image that Doctoral/Research institutions have which put these institutions in such a demand that an increase in out-of-state tuition and fees would not significantly reduce the enrollment.

In the literature, prior research about the prestige of Doctoral/Research universities (Geiger, 2004; Volkwein \& Sweitzer, 2006) and domestic student preference studies (Baryla \& Dotterweich, 2006; Bourke, 2000; Gutman \& Miaoulis, 2003) pointed out that institutions had gone through various evaluations and met certain quality related criteria when they were classified as Doctoral/Research institutions. So, it is generally accepted by the wide public that Doctoral/Research institutions have richer resources and 
stronger capability to provide high quality education to their students. They usually have a far larger number of qualified applicants among the student pool than the desired enrollment level. As a result, even with an increase in its price, those institutions are still able to attract enough qualified applicants although their number might decrease. Doctoral/Research institutions do charge higher tuition and fees than the average tuition level of all the institutions, international undergraduate students are still attracted to enroll since they may believe the high quality education Doctoral/Research institutions supposed to offer deserves their money.

In addition, international undergraduate students may hear more about Doctoral/Research institutions from the most popular ranking systems for worldwide universities. They tend to be convinced that research accomplishment is also the most critical criterion for judging the quality of a higher education institution. However, there are questions and arguments going on about whether Doctoral/Research institutions are the best destination for undergraduate students although they may be a better choice for graduate students. Among others, the mostly cited critics about Doctoral/Research institutions is they heavily rely on graduate teaching assistants or adjunct instructors to teach and advise undergraduate students (Luft, Kurdziel, Roehrig, \& Turner, 2004).

Another general result this finds out is the relationship between tuition increase and international undergraduate student enrollment is remarkably different between public and private institutions. It is noteworthy that public institutions have experienced a much larger increase in out-of-state tuition and fees than private institutions during both of the two sample periods but still receive large number of international undergraduate student enrollment during the same period of time. This aligns with the results of prior 
research that for public institutions, poor economic conditions and subsequent state budget cuts have created a fertile landscape for large tuition increases and the pressures are still increasing (Hemelt \& Marcotte, 2011).

Numerous researches have confirmed that domestic students are price sensitive and the continuous raising of tuition and fees is negatively influencing student enrollment. Even worse, the pool of traditional domestic undergraduate students is shrinking. Thus, there is limited space for public institutions to increase tuition and fees to its potential domestic undergraduate students (Paulson, 1990). However, it is claimed that international undergraduate students have showed to be a stable and robust source of revenue in the past decade and in future and therefore, public institutions could design and implement relevant strategies to attract more international undergraduate students to meet their revenue needs.

For private institutions, they have more diversified sources of revenue and generally speaking, they charge higher tuition and fees than their public counterparts. However, unlike the common trend showed in domestic student demand studies in the literature, where the price goes up and the student enrollment goes down, private institutions steadily receive the increasingly high number of international undergraduate student during the two sample data periods although they kept increasing their out-ofstate tuition and fees. In fact, an increase in tuition and fees at private research institutions might actually increase the international undergraduate student demand for the reasons of conspicuous consumption and status-seeking as advanced by Thorstein Veblen (1899). 
In addition, for international undergraduate students who choose to attend the more expensive private institutions, tuition and fees may have other implications beyond the cost of an international higher education. Considering their expected economic returns of attending prestigious private institutions students and their families may choose high-priced institutions in the belief that high price means high quality (e.g., Zhang, 2005). If this logic holds, then it is understandable that the demand function of private research institutions, especially at those most prestigious institutions, might deviate from the standard downward sloping curve suggested by common demand theory.

\section{Implications for Theory and Institutional Policy}

\section{Implications for Demand Theory}

Demand theory applied to higher education suggests that enrollment would decrease as tuition increases and inversely, enrollment would increase when tuition decreases, as a general agreement in prior studies (Heller, 1997; Leslie \& Brinkman, 1987). It helps explain many phenomena and trends in related to estimating the effect of tuition on the investment and the outcomes of higher education. However, it is important to understand that tuition elasticity of a certain group of students in higher education do not necessarily adhere to those standard market principles. Most likely, international undergraduate students come to U.S. institutions due to the perceptions of the quality of education and not because U.S. higher education institutions provide them the best price they can found around the globe. There are more comprehensive reasons than the best price is being offered. Their choice of consumption could be based on academic curriculums, reputation of faculty and staff services, job market potentials, and other additional values that either strictly or loosely bounded with the institutional price factors. 
It is also noteworthy that the increasing number of international undergraduate students has depicted a shift in international study from an elitist experience to one involving mass movements (Naidoo, 2010). Different from before, for many of today's international undergraduate students, studying abroad may be the only way of pursuing higher education due to access related problems in their own countries (Alam \& Rahaman, 2008). In addition, Chickering and Havighurst (1981) suggest students at different stages of life have differing needs that influences their educational and career goals. International undergraduate students may have and display different expectations of U.S. higher education than international graduate students. Therefore, theory and practice applied in international graduate student research may not be appropriate with international undergraduate students. There is a strong need to better understand the unique enrollment trend and pattern of international undergraduate students in U.S. higher education.

Admittedly, demand studies based on domestic students have established an irreplaceable foundation for understanding the enrollment behavior of international undergraduate student enrollment in U.S. institutions. However, this study suggests that those principles and guideline widely agreed in domestic student enrollment studies may not apply to international student studies. Especially for international undergraduate students, with younger age and diverse academic, social and cultural backgrounds, fullfee paying feature, and limited learning or living experience in unfamiliar environments, choosing an institution in a foreign country is a much more complex undertaking than domestic students or even international graduate students. It is the goal of this study to enrich the demand theory research by adding efforts to examine factors specifically 
affecting international undergraduate students to make sure their important education investment is a win-win decision to both themselves and U.S. higher education institutions.

\section{Implications for Institutional Policy}

The findings of this study could have implications to the policymaking in U.S. higher education institutions. It is important for institutions where international undergraduates are playing increasingly important roles in concentrate more effort on their international undergraduate enrollment management, become more responsive to market interests, be more aware of the increasingly competitive nature of international student recruitment process, and actively engage in market-oriented activities intended to attract desired students to their campuses. This also urges individual institutions to seek best-fit ways to make itself more attractive than its competitors in the eyes of desired international undergraduate students.

Based on the findings of this study that tuition and fees change has been proved not a significant factor affecting the international undergraduate student enrollment in U.S. higher education institutions in general during the 20 years period, tuition increase can be used as a lever for some institutions who are suffering revenue loss in short term and looking for a breakthrough to recover from this situation. Incorporating with their unique characteristics, institutions could strategically use tuition increase to international undergraduate students and strive for accumulating revenues for providing better education to their students.

However, institutions who choose to use tuition increase as a strategy to improve their financial situation should take cautions not to slowly overprice themselves out of the 
international student market. Although the numbers of international students choose to come to the U.S. pursuing undergraduate education in these two decades are increasing competition from peer institutions are becoming severe. If an institution determined to increase its price, it must exert more efforts to engage in improving the quality of its education experience to international undergraduate students as well.

Similarly, it is important to take cautions as well for certain public institutions which have concerns about their low international undergraduate student enrollment and choose to use tuition decrease as a strategy to improve their situation. This study agrees with previous studies (Hemelt \& Marcotte, 2011) that public institutions have only limited discretion in setting out-of-state enrollment levels, even if a reduction in tuition level led to a large increase in international undergraduate student demand, public institutions are less likely to benefit financially from it. Given the documented decrease in government funding for public institutions and the important revenue-generating function of international undergraduate students, it is possible that public institutions might increase international undergraduate student enrollment carefully increasing their enrollment capacity or lowering admissions to in-state students rather than by decreasing their out-of-state tuition and fees.

For those institutions which do not have financial concerns, but want to improve their international undergraduate enrollment for other purposes, like the more prestigious private institutions, should also be careful to use the tuition decrease as a strategy as traditional student demand theory suggested. Generally speaking, lowering tuition rates may not be an effective strategy for increasing their international undergraduate student enrollment owing to the fact that tuition is not identified as a significant factor affecting 
the enrollment decision of international undergraduate students. Therefore, a reduction in tuition rate for international undergraduate students could risk decreasing the current tuition revenues generated from enrolling international undergraduate students and also leading to the misperception of lowering the education quality of the institution.

\section{Limitations of This Study and Implications for Future Research}

Although this study expects its research results to have strong generalizability in higher education due to its national level quality data source and large sample size, there are limitations. The implications of this study for future research are based on the limitations of this current study. First, the institution types included in the sample of this study are limited to the four-year degree/certificate offering institutions broadly classified by control (public and private) and those included in the first three categories of Carnegie 2005 Classifications only, namely, Doctoral/Research, Master's and Bachelor's institutions (those Associate's, specialized or tribal institutions are not included in the samples). For example, approximately $18 \%$ of international students studying at two-year and specialized institutions (Open Doors, 2009) are not included in this study. Ideally, the inclusion of other types of institutions would result in a more complete study and would allow for a better understanding of the dynamics of tuition effects on international undergraduate student enrollment. Thus, it would be beneficial for future studies to consider further examining and testing the relationship between tuition increases and international student enrollment by including other institution types or grouping institutions in different ways.

The second limitation of the study relates to the nature of some of the data used in the empirical model. The tuition and fees variable, for instance, is used as a measure of 
the price of an institution for the convenience of data availability in the data source. It does not include room and board and other education related expenses which could be very different across different geographic locations in the U.S. (Abraham \& Clark, 2006; Baird, 2006; Stinebrickner \& Stinebrickner, 2003). As tuition and fees are just one part of the total estimated cost of attendance for international undergraduate students to choose from different educational institutions, it does not fully estimate the relationship between student enrollment and the cost of attendance in an institution. Consequently, there is a need for individual institutions to undertake their own pricing analysis to review the elasticity of international undergraduate students to tuition and fees increases at their particular institution.

Last but not least, this study has to rely on institutional level, group data rather than individual student level data so that it is unable to reflect student characteristics variation across individual students. In this study, international undergraduate students are considered as one group of students without considering their unique characteristics because of country of origins, social class status, their interests of academic fields, and etc. This lack of individual student level data also forced this study to drop some variables which have been proved to have strong predicting power to domestic student enrollment, like financial aid, student's family income. The reasons for omitting these variables are two-fold: first, there is no adequate information exists on the number of teaching or research assistantships open to foreign students and financed by U.S. research contracts and grants with universities; second, IPEDS, as a comprehensive institutional level data set, do not collect student level information. Thus, it would be beneficial if 
future studies could diversify data sources to include more student level data into fuller consideration.

\section{Conclusion}

This study has achieved its research purpose of examining the relationship between international undergraduate student enrollment and changes in U.S. higher education institutional tuition and fees. This study finds out as a unique student group with continuously increasing numbers on U.S. campuses, international undergraduate students are generally inelastic to the changes of tuition and fees during the last two decades (1991-2010), but tend to become less inelastic than before in recent years (20052010). However, this general inelastic relationship between international undergraduate enrollment and tuition and fees can vary significantly across different institution types either by Carnegie Classifications or by controls.

Thus, the findings of this study have significance to both student demand theory and higher education institutional policy-making. On the one hand, this study implies student demand theory based upon domestic students provides an irreplaceable foundation for understanding the enrollment behavior of international students at U.S. institutions but need more in-depth development to better apply to international undergraduate student group. On the other hand, this study implies tuition increase can be used strategically by some institutions to improve their revenue situation in a short run but need to take cautions not to slowly overprice themselves out of the market and lose the expected benefits of hosting international undergraduate students.

For future research, this study recommends that it would be beneficial to consider further examining the relationship between tuition increases and international 
undergraduate student enrollment by diversifying data sources to include more relevant variables for measuring both institutional and student characteristics. In addition, future research could expand the scope of this current study which focused on institutional level enrollment within four-year institutions by including other institution types or grouping institutions in different ways to explore and test the impact of tuition increase on international undergraduate student enrollment at various levels of interests. 


\section{REFERENCES}

Abelmann, N., \& Kang, J. (2013). A fraught exchange? U.S. media on Chinese international undergraduates and the American university. Journal of Studies in International Education, 17(1), 1-16.

Abraham, K. G., \& Clark, M. A. (2006). Financial aid and students' college decisions evidence from the District of Columbia Tuition Assistance Grant Program. Journal of Human Resources, 41(3), 578-610.

Agarwal, V. B., \& Winkler, D. R. (1985). Foreign demand for United States higher education: A study of developing countries in the eastern hemisphere. Economic Development and Cultural Change, 33(3), 623-644.

Aguilera, M. B., \& Massey, D. S. (2003). Social capital and the wages of Mexican migrants: New hypotheses and tests. Social Forces, 82(2), 671-701.

Alam, G. M. (2009). Can governance and regulatory control ensure private higher education as business or public goods in Bangladesh? Afr. J. Bus. Manage, 3(12), 890-906.

Alam G. M. \& Rahaman, M. (2008). The impact of migration on development: A comparative study between skilled and semi/unskilled emigrants. Journal of Business Studies, 4, 117-131.

Altbach, P.G., \& Wang, J. (1989). Foreign Students and International Study: Bibliography and Analysis, 1984-1988. Lanham, MD: University Press of America.

Altbach, P. G. (2004). Globalization and the university: Myths and realities in an unequal world. Tertiary Education and Management, 10(1), 3-25. 
Altbach, P. G., \& Knight, J. (2007). The internationalization of higher education: Motivations and realities. Journal of Studies in International Education, 11(3-4), 290-305.

Astin, A. W. (1972). College Dropouts: A National Profile. Washington, DC: American Council on Education.

Bailey, B. L. (2006). Let the data talk: Developing models to explain IPEDS graduation rates. New Directions for Institutional Research, 131, 101-115.

Baird, K. (2006). Access to college: The role of tuition, financial aid, scholastic preparation and college supply in public college enrollments. Journal of Student Financial Aid, 36(3), 16-38.

Barger, S. S. (2004). The Impact of International Students on Domestic Students in U.S. Institutions of Higher Education (Unpublished doctoral dissertation). University of Wisconsin, Madison.

Baryla, E., \& Dotterweich, D. (2006). Institutional focus and non-resident student enrollment. International Journal of Educational Management, 20, 239-248.

Basch, D. L. (1999). Changes in the endowment spending of private colleges in the early 1990s. Journal of Higher Education, 278-308.

Becker, R., \& Kolster, R. (2012). International student recruitment: Policies and developments in selected countries. The Hague, The Netherlands: NUFFIC (Netherlands Organisation for International Cooperation in Higher Education).

Borjas, G. J. (2004). Do foreign students crowd out native students from graduate programs? (No. w10349). National Bureau of Economic Research. 
Bourdieu, P. (1986). Forms of capital. in John G. Richardson (ed.), Handbook of Theory and Research for the Sociology of Education. Greenwood, New York.

Buckley, P. J. (1996). The role of management in international business theory: A metaanalysis and integration of the literature on international business and international management. MIR: Management International Review, 7-54.

Buddington, S. A. (2002). Acculturation, psychological adjustment (stress, depression, self-esteem) and the academic achievement of Jamaican immigrant college students. International Social Work, 45(4), 447-464.

Bybell, D., Jackson, M., \& Ray, S. (2013). International students in the US: Social and psychological adjustment, Journal of International Students, 3(1).

Cadman, K. (1997). Thesis writing for international students: A question of identity?. English for Specific Purposes, 16(1), 3-14.

Carter, D. F. (1999). The impact of institutional choice and enrironments on AfricanAmerican and White students' degree expectations. Research in Higher Education, 40(1), 17-41.

Cellini, S. R. (2008). Causal inference and omitted variable bias in financial aid research: Assessing solutions. Review of Higher Education, 31, 329-354.

Chang, M., Astin, A., \& Kim, D. (2004). Cross-racial interaction among undergraduates: Some consequences, causes, and patterns. Research in Higher Education, 45(5), 529-553.

Chapman, D. W. (1981). A model of student college choice. The Journal of Higher Education, 490-505. 
Chellaraj, G., Maskus, K. E., \& Mattoo, A. (2008). The contribution of international graduate students to US innovation. Review of International Economics, 16(3), 444-462.

Chickering, A. W. \& Havighurst, R. J. (1981). The life cycle. In Chickering and Associates: The Modern American College, 16-50. San Francisco, CA: JosseyBass.

Chirkov, V., Vansteenkiste, M., Tao, R., \& Lynch, M. (2007). The role of selfdetermined motivation and goals for study abroad in the adaptation of international students. International Journal of Intercultural Relations, 31(2), 199-222.

Choudaha, R. \& Chang, L. (2012).Trends in international student mobility. World Education News \& Reviews, 25(2), available at: http://www.wes.org/ras/TrendsInInternationalStudentMobility.pdf (accessed March 2013).

Christie, C. A., \& Fleischer, D. N. (2010). Insight into evaluation practice: A content analysis of designs and methods used in evaluation studies published in North American evaluation-focused journals. American Journal of Evaluation, 31(3), 326-346.

Clarke, M. (2007). The impact of higher education rankings on student access, choice, and opportunity. Higher Education in Europe, 32(1), 59-70.

Clayson, D. E., \& Haley, D. A. (2005). Marketing models in education: students as customers, products, or partners. Marketing Education Review, 15(1), 1-10. 
Cohen, A. M. (2003). College size as the major discriminator. New Directions for Community Colleges, 2003(122), 39-46.

Cole, D., \& Ahmadi, S. (2003). Perspectives and experiences of Muslim women who veil on college campuses. Journal of College Student Development, 44(1), 47-66.

Constantine, M. G., Kindaichi, M., Okazaki, S., Gainor, K. A., \& Baden, A. L. (2005). A qualitative investigation of the cultural adjustment experiences of Asian international college women. Cultural Diversity and Ethnic Minority Psychology, 11(2), 162-174.

Cooke, T. J., \& Boyle, P. (2011). The migration of high school graduates to college. Educational Evaluation and Policy Analysis, 33(2), 202-213.

Curs, B., \& Singell, L. (2002). An analysis of the application and enrollment processes for in-state and out-of-state students at a large public university. Economics of Education Review, 21, 111-124.

Cushner, K. \& Mahon, J. (2002). Overseas student teaching: Affecting personal, professional and global competencies in an age of globalization. Journal of Studies in International Education, 6(1), 44-59.

Dollag, B. (2004). Wanted: Foreign students. The Chronicle of Higher Education, 51(7), A37.

Dotterweich, D., \& Baryla, E. (2005). Non-resident tuition and enrollment in higher education: Implications for tuition pricing. Education Economics, 13, 375-385.

Douglass, J. A. (2006). The waning of America's higher education advantage: International competitors are no longer number two and have big plans in the 
global economy. Research and Occasional Papers Series. Center for Studies of Higher Education (CSHE).

Douglass, J. A. \& Edelstein, R. (2009). The global competition for talent: The rapidly changing market for international students and the need for strategic approach in the US. Research and Occasional Papers Series. Center for Studies of Higher Education (CSHE).

Dreher, A. \& Poutvaara, P. (2011). Foreign students and migration to the United States. World Development, doi: 10.1016/j.worlddev.2010.12.001

Ehrenberg, R. G. (2000). Tuition Rising: Why College Costs So Much, With a New Preface. Harvard University Press.

Engberg, M. E., \& Allen, D. J. (2011). Uncontrolled destinies: Improving opportunity for low-income students in American higher education. Research in Higher Education, 52(8), 786-807.

Fethke, G. (2011). A low-subsidy problem in public higher education. Economics of Education Review, 30(4), 617-626.

Fitzgerald, B. K., \& Kane, T. (2006). Lowering barriers to college access: Opportunities for more effective coordination of state and federal student aid policies. In Expanding Opportunity in Higher Education: Leveraging Promise, 53-74.

Furnham, A., \& Alibhai, N. (1985). The friendship networks of foreign students: A replication and extension of the functional model. International Journal of Psychology, 20(3-4), 709-722.

Galloway, F. J., \& Jenkins, J. R. (2005). The adjustment problems faced by international students in the United States. NASPA Journal, 42, 175-187. 
Geiger, R. L. (2004). Knowledge and Money: Research Universities and the Paradox of the Marketplace. Stanford University Press.

González, C. R., Mesanza, R. B., \& Mariel, P. (2011). The determinants of international student mobility flows: An empirical study on the Erasmus program. Higher Education, 62(4), 413-430.

Grey, M. (2002). Drawing with difference: Challenges faced by international students in an undergraduate business degree. Teaching in Higher Education, 7(2), 153-166.

Green, M. F., Marmolejo, F., \& Egron-Polak, E. (2012). The internationalization of higher education. The SAGE Handbook of International Higher Education, 439.

Gurin, P., Dey, E. L., Hurtado, S., \& Gurin, G. (2002). Diversity and higher education: Theory and impact on educational outcomes. Harvard Educational Review, 72(3), 330-367.

Guruz, K. (2011). Higher Education and International Student Mobility in the Global Knowledge Economy. SUNY Press.

Hardy, D. E., \& Katsinas, S. G. (2006). Using community college classifications in research: From conceptual model to useful tool. Community College Journal of Research and Practice, 30(4), 339-358.

Hearn, J. C., \& Longanecker, D. (1985). Enrollment effects of alternative postsecondary pricing policies. The Journal of Higher Education, 485-508.

Heaton, C., \& Throsby, D. (1998). Benefit-cost analysis of foreign student flows from developing countries: the case of postgraduate education. Economics of Education Review, 17(2), 117-126.

Heller, D. E. (1997). Student price response in higher education: An update to Leslie and 
Brinkman. Journal of Higher Education, 68(6), 624-659.

Heller, D. E. (1999).The effects of tuition and state financial aid on public college enrollment. The Review of Higher Education, 23(1), 65-89.

Hemelt, S. W., \& Marcotte, D. E. (2011). The impact of tuition increases on enrollment at public colleges and universities. Educational Evaluation and Policy Analysis, 33(4), 435-457.

Higdon, L. I., Jr. (2003). Change from within: The challenge of shaping the institutional culture. Liberal Education 89 (1): 64-68.

Hindrawan, J. J. (2003). International student recruitment since 9/11, Part I: What is the fallout from the war on terrorism? World Education News \& Reviews, 16(2).

Hossler, D. (1984). Enrollment Management: An Integrated Approach. College Board Publications, Box 886, New York, NY 10101.

Hossler, D., \& Gallagher, K. S. (1987). Studying student college choice: A three-phase model and the implications for policymakers. College and University, 62(3), 207221.

Jackson, G. A., \&Weathersby, G. B. (1975). Individual demand for higher education: A review and analysis of recent empirical studies. The Journal of Higher Education, 623-652.

Jacoby, D. (2006). Effects of part-time faculty employment on community college graduation rates. The Journal of Higher Education, 77(6), 1081-1103.

John, E. P. S. (1990). Price response in enrollment decisions: An analysis of the high school and beyond sophomore cohort. Research in Higher Education, 31(2), 161176. 
Joseph, M., \& Joseph, B., (2000). Indonesian students' perceptions of choice criteria in the selection of a tertiary institution: Strategic implications. The International Journal of Educational Management, 14(1), 40-44.

Kane, T. J. (2004). College-going and inequality. Social Inequality, 319-354.

Kaufman, H., \& Goodman, A. E. (2002). Institute of International Education Annual Report. Washington, DC: Institute of International Education. Available at http://www.iie.org

Kher, N., Juneau, G., \& Molstad, S. (2003). From the southern hemisphere to the rural south: A Mauritian student's version of "coming to America". College Student Journal, 37(4), 564-568.

Kimmel, K., \& Volet, S. (2012). University students' perceptions of and attitudes towards culturally diverse group work: Does context matter? Journal of Studies in International Education, 16(2), 157-181.

Koehne, N. (2006). (Be) Coming, (Be) Longing: Ways in which international students talk about themselves. Discourse: Studies in the Cultural Politics of Education, 27(2), 241-257.

Kolster, R. (2010). Academic attractiveness of countries to students: explaining and measuring a countries' academic $\mathrm{X}$ factor.

Kwiek, M. (2001). Globalization and higher education. Higher Education in Europe, $X X \operatorname{VI}(1), 27-38$.

Lange, T. (2012). Return migration of foreign students and non-resident tuition fees. Journal of Population Economics, 26(2), 703-718.

Larsen, K., \& Vincent-Lancrin, S. (2002). International trade in educational services: 
Good or bad? Higher Education Management and Policy, 14(3), 9-45.

Lawley, M. (1997). Thai and Malaysian students' perceptions of overseas study destinations: an exploratory study (Doctoral dissertation, University of Southern Queensland).

Lowell, B. L., Bump, M., \& Martin, S. (2007). Foreign students coming to America. Washington: Institute for the Study of International Migration.

Lee, J. (2008). Beyond borders: International students pathways to the United States. Journal of Studies in International Education, 12(3), 308-327.

Lee, J., \& Rice, C. (2007). Welcome to America? International student perceptions of discrimination. Higher Education, 53(3), 381-409.

Lee, K. H., \& Tan, J. P. (1984). The international flow of third level lesser developed country students to developed countries: Determinants and implications. Higher Education, 13, 687-707.

Leslie, L. L. \& Brinkman, P. T. (1987). Student price response in higher education. Journal of Higher Education, 58, 181-204.

Leslie, L. L., Johnson, G. P., \& Carlson, J. (1977). The impact of need-based student aid upon the college attendance decision. Journal of Education Finance, 2(3), 269-285.

Lewis, G. H., \& Morrison, S. (1975). A longitudinal study of college selection (2). Technical Report.

Li, M., \& Bray, M. (2007). Cross-border flows of students for higher education: Pushpull factors and motivations of mainland Chinese students in Hong Kong and Macau. Higher Education, 53(6), 791-818.

Litten, L. H., \& Brodigan, D. L. (1982). On Being Heard in a Noisy World: Matching 
Messages and Media in College Marketing. College and University, 57(3), 242-64.

Litten, L. H., Sullivan, D. \& Brodigan, D. L. (1983). Applying Market Research in College Admissions. New York: College Entrance Examination Board.

Luft, J. A., Kurdziel, J. P., Roehrig, G. H., \& Turner, J. (2004). Growing a garden without water: Graduate teaching assistants in introductory science laboratories at a doctoral/research university. Journal of Research in Science Teaching, 41(3), 211-233.

Lulat, Y. M. \& Cordaro, J. (1984). International students and study abroad programs: a select bibliography. Comp. Educ. Rev, 28(2):300-339.

Magaya, A. (2004). Recruitment strategies of international students: Trends and patterns in public universities in the state of Illinois (Doctoral dissertation, Southern Illinois University Carbondale).

Malaney, G. D. (1984). An analysis of financial aid in the recruitment of graduate students at the Ohio State University. Journal of Student Financial Aid, 14(1), 1119.

Marginson, S. (2004). Competition and markets in higher education: A glonacal analysis. Policy Futures in Education, 2(2), 175-244.

Mazzarol, T. (1998). Critical success factors for international education marketing. International Journal of Educational Management, 12(4), 163-175.

Mazzarol, T., \& Soutar, G. N. (2002). "Push-pull" factors influencing international student destination choice. International Journal of Educational Management, 16(2/3), 82-90.

Mazzarol, T., Soutar, G. N. \& Seng, M. S. Y. (2003). The third wave: Future trends in 
international education. The International Journal of Educational Management, 17(3), 90-99.

McCormack, E. (2005). Enrollment of foreign students falls for a $2^{\text {nd }}$ year". The Chronicle of Higher Education, 52(13), A1-A5.

McCormack, E., Neelakantan, S., \& Overland, M. A. (2007). Number of foreign students bounces back to near-record high. The Chronicle of Higher Education, 54(12), A1A36.

McMahon, M. E. (1992). Higher education in a world market. Higher Education, 24(4), $465-482$.

McPherson, M. S., \& Schapiro, M. O. (1991). Does student aid affect college enrollment? New evidence on a persistent controversy. The American Economic Review, 81(1), 309-318.

MixonJr, F. G. (1992). Factors affecting college student migration across states. International Journal of Manpower, 13(1), 25-32.

Mixon Jr, F. G., \& Hsing, Y. (1994). The determinants of out-of-state enrollments in higher education: A tobit analysis. Economics of Education Review, 13(4), 329-335.

Mooney, P., \& Neelakantan, S. (2004). No longer dreaming of America. The Chronicle of Higher Education, A41-A43.

Mpinganjira, M. (2009). Comparative analysis of factors influencing the decision to study abroad. African Journal of Business Management, 3(8), 358-365.

Murphy, P. E. (1981). Consumer buying roles in college choice: Parents' and students' perceptions. College and University, 56(2), 140-50.

Murray, D., Hall, R., Leask, B., Marginson, S., \& Ziguras, C. (2011). State of current 
research in international education. In Background paper for AEI supported International Education Research policy symposium, April (Vol. 8).

NAFSA. (2003). In America's Interest: Welcoming International Students. Washington D.C.: NAFSA.

Naidoo, V. (2007). Research on the flow of international students to UK universities determinants and implications. Journal of Research in International Education, 6(3), 287-307.

Nutting, A. W. (2013). Tuition and the outcomes of community college attendance: simulations for academic-program and occupational-program students. Education Economics, 1-21.

Open Doors. (2009). Fast Facts Open Doors. Press Release by the Institute of International Education.

Open Doors. (2010). International student enrolments declined by 2.4\% in 2009/10. Press Release by the Institute of International Education.

Open Doors.(2013). Fast Facts Open Doors. Press Release by the Institute of International Education.

Oprean, C. (2007). Adequately responding to "reform" and "anti-reform" pressures in the Romanian higher education system under the Bologna Process. Higher Education in Europe, 32(1), 91-97.

Ostheimer, R. H. (1953). Student charges and financing higher education. Columbia University Press.

Padlee, S. F., Kamaruddin, A. R., \& Baharun, R. (2010). International students' choice behavior for higher education at Malaysian private universities. International 
Journal of Marketing Studies, 2(2), 202-216.

Paulsen, M. B. (1990). College Choice: Understanding Student Enrollment Behavior. ASHE-ERIC Higher Education Report, 6. The George Washington University, Washington, DC.

Paulsen, M. B., \& St John, E. P. (2002). Social class and college costs: Examining the financial nexus between college choice and persistence. The Journal of Higher Education, 73(2), 189-236.

Pavel, M. D., \& Reiser, M. (1991). Using national data bases to examine minority student success in higher education. New Directions for Institutional Research, 69, 5-20.

Pimpa, N. (2005). A family affair: The effect of family on Thai students' choices of international education. Higher Education, 49(4), 431-448.

Perna, L. W. (2006). Studying college access and choice: A proposed conceptual model. In Higher Education, 99-157.Springer Netherlands.

Rhee, J. E., \& Sagaria, M. A. D. (2004). International students: Constructions of imperialism in the chronicle of higher education. The Review of Higher Education, 28(1), 77-96.

Robertson, S. L. (2008). Embracing the global: Crisis and the creation of a new semiotic order to secure Europe's knowledge-based economy. Education and the Knowledge-based Economy in Europe. Netherlands: Sense Publications.

Robertson, M., Line, M., Jones, S., \& Thomas, S. (2000). International students, learning environments and perceptions: A case study using the Delphi technique. Higher Education Research and Development, 19(1), 89-102.

Romano, R. M., \& Djajalaksana, Y. M. (2011). Using the community college to control 
college costs: how much cheaper is it? Community College Journal of Research and Practice, 35(7), 539-555.

Rose-Redwood, C. R. (2010). The Challenge of Fostering Cross-Cultural Interactions: A Case Study of International Graduate Students' Perceptions of Diversity Initiatives. College Student Journal, 44(2), 389-399.

Ross, M., Heaney, J., \& Cooper, M. (2007). Institutional and managerial factors affecting international student recruitment management. International Journal of Educational Management, 21(7), 593-605.

Sanderson, G. (2004). Existentialism, globalization and the cultural other. International Education Journal, 4(4), 1-20.

Selvadurai, R. (1992). Problems faced by international students in American colleges and universities. Community Review, 12(1), 27-32.

Selvaratnam, V. (1985). The international flow of scholars and students: A vehicle for cross-cultural understanding, international co-operation and global development? International Journal of Educational Development, 5(4), 307-323.

Schneider, B., Carnoy, M., Kilpatrickk, J., Schmidt, W. H., \& Shavelson, R. J. (2007). Estimating causal effects: Using experimental and observational designs. Washington, DC: American Educational Research Association.

Schuh, J. H. (2002). The integrated postsecondary education data system. New Directions for Higher Education, 2002(118), 29-38.

Schuh, J. H., \& Shelley, M. C. (2001). A longitudinal analysis of funding for student affairs in public institutions. Journal of College Student Development, 42(5), 45664. 
Scott, G. A. (2007). Challenges in attracting international students to the United States and implications for global competitiveness. Testimony before the Subcommittee on International Organizations, Human Rights and Oversight, Committee on Foreign Affaires, House of Representatives, United States Government Accountability Office (GAO).

Shachar, A. (2006). Race for talent: Highly skilled migrants and competitive immigration regimes, The. NYUL Rev., 81, 148.

Shah, A., \& Laino, H. (2006). Marketing a US university to international students: Which approach is best-standardization, adaptation, or contingency? An investigation of consumer needs in seven countries. Journal of Marketing for Higher Education, $16(1), 1-24$.

Sharma, M. P., \& Mulka, J. S. (1993). The Impact of International Education upon United States Students in Comparative Perspective.

Shin, J. C., \& Milton, S. (2006). Rethinking tuition effects on enrollment in public fouryear colleges and universities. The Review of Higher Education, 29(2), 213-237.

Sinclair, J. (2010). International Enrollment Management: Framing the Conversation.

Sklair, L. (2001). Transnational capitalist class. Blackwell Publishing Ltd.

Smith, L. M., \& Rae, A. N. (2006). Coping with demand: Managing international student numbers at New Zealand universities. Journal of Studies in International Education, 10(1), 27-45.

Soo, K. T., \& Elliott, C. (2010). Does price matter? Overseas students in UK higher education. Economics of Education Review, 29(4), 553-565. 
Staniscia, B. (2012). Mobility of students and attractiveness of universities. The case of Sapienza University of Rome. International Review of Sociology, 22(2), 245-258.

Stinebrickner, R., \& Stinebrickner, T. R. (2003). Understanding educational outcomes of students from low-income families evidence from a liberal arts college with a full tuition subsidy program. Journal of Human Resources, 38(3), 591-617.

Strauss, L. C., \& Volkwein, J. F. (2004). Predictors of student commitment at two-year and four-year institutions. The Journal of Higher Education, 75(2), 203-227.

Szelest, B. P. (2003). A systems dynamic assessment of organization strategic goal realization: Case study of a public research university, Dissertation, State University of New York at Albany.

Tremblay, K. (2002). Student mobility between and towards OECD countries: A comparative analysis. International Mobility of the Highly Skilled, 39-67.

Vincent-Lancrin, S. (2004). Building capacity through cross-border tertiary education. Cross Border Higher Education for Development, 4.

Volkwein, J. F., \& Grunig, S. D. (2005). Resources and reputation in higher education: Double, double, toil and trouble. Achieving Accountability in Higher Education: Balancing Public, Academic, and Market Demands, 246-274.

Volkwein, J. F., Malik, S. M., \& Napierski-Prancl, M. (1998). Administrative satisfaction and the regulatory climate at public universities. Research in Higher Education, 39(1), 43-63.

Volkwein, J. F., \& Sweitzer, K. V. (2006). Institutional prestige and reputation among research universities and liberal arts colleges. Research in Higher Education, 47(2), 129-148. 
Wandering Scholars. (2005). The brains business. A survey of higher education. The Economist, 10, 16-18.

Wang, C. C. D., \& Mallinckrodt, B. (2006). Acculturation, attachment, and psychosocial adjustment of Chinese/Taiwanese international students. Journal of Counseling Psychology, 53(4), 422.

Waters, J. L. (2006). Geography of cultural capital: education, international migration and family strategies between Hong Kong and Canada. Transactions of the Institute of British Geographers, 31(2), 179-192.

Williams, A. M. (2007). International labor migration and tacit knowledge transactions: a multi-level perspective. Global Networks, 7(1), 29-50.

Williams, P. (1981). The overseas student question. Studies for A Policy. Heinemann Educational Books Inc., 4 Front Street, Exeter, NH 03833.

Winston, G. C. (1999). Subsidies, hierarchy and peers: The awkward economics of higher education. The Journal of Economic Perspectives, 13(1), 13-36.

Wobbekind, R. L., \& Graves, P. E. (1989). International student demand for higher education in the United States. Research in Higher Education, 30(3), 273-299.

Ye, J. (2006). Traditional and online support networks in the cross-cultural adaptation of Chinese international students in the United States. Journal of ComputerMediated Communication, 11(3), 863-876.

Ying, Y. W. (2005). Variation in acculturative stressors over time: A study of Taiwanese students in the United States. International Journal of Intercultural Relations, 29(1), 59-71. 
Zhang, L. (2007). Nonresident enrollment demand in public higher education: An analysis at national, state, and institutional levels. The Review of Higher Education, 31(1), 1-25.

Zhang, L. (2010). The use of panel data models in higher education policy studies. In Higher Education: Handbook of Theory and Research, 307-349. Springer Netherlands.

Zhao, C. M., Kuh, G. D., \& Carini, R. M. (2005). A comparison of international student and American student engagement in effective educational practices. Journal of Higher Education, 209-231. 
VITA

Jie Zhang has a B.A. degree majored in English Education and a M.A. degree majored in English Linguistics from Hebei Normal University, China. In 2000, she started to teach College English at Beijing Jiaotong University, China. In 2006, she went to Europe for her second M.A. degree majored in Higher Education. She spent one semester at University of Oslo, Norway, one semester at University of Aveiro, Portugal, and two semesters at University of Tampere, Finland. Then in 2008, she came to University of Missouri to pursue her PhD degree in Higher Education Administration. She began her career as a Senior Research and Planning Associate at Baylor University since May, 2013 which was one year before her graduation from University of Missouri. 